Review Article

\title{
Pharmacological Effects of Active Compounds on Neurodegenerative Disease with Gastrodia and Uncaria Decoction, a Commonly Used Poststroke Decoction
}

\author{
Stanley C. C. Chik, Terry C. T. Or, D. Luo, Cindy L. H. Yang, and Allan S. Y. Lau \\ Molecular Chinese Medicine Laboratory, Li Ka Shing Faculty of Medicine, The University of Hong Kong, \\ Hong Kong Special Administrative Region, Hong Kong
}

Correspondence should be addressed to Cindy L. H. Yang; cindyy@hku.hk and Allan S. Y. Lau; asylau@hku.hk

Received 27 August 2013; Accepted 17 September 2013

Academic Editors: C.-L. Hsieh, B.-Y. Zeng, and K. Zhao

Copyright (C) 2013 Stanley C. C. Chik et al. This is an open access article distributed under the Creative Commons Attribution License, which permits unrestricted use, distribution, and reproduction in any medium, provided the original work is properly cited.

Neurodegenerative diseases refer to the selective loss of neuronal systems in patients. The diseases cause high morbidity and mortality to approximately 22 million people worldwide and the number is expected to be tripled by 2050 . Up to now, there is no effective prevention and treatment for the neurodegenerative diseases. Although some of the clinical therapies target at slowing down the progression of symptoms of the diseases, the general effectiveness of the drugs has been far from satisfactory. Traditional Chinese medicine becomes popular alternative remedies as it has been practiced clinically for more than thousands of years in China. As neurodegenerative diseases are mediated through different pathways, herbal decoction with multiple herbs is used as an effective therapeutic approach to work on multiple targets. Gastrodia and Uncaria Decoction, a popular TCM decoction, has been used to treat stroke in China. The decoction contains compounds including alkaloids, flavonoids, iridoids, carotenoids, and natural phenols, which have been found to possess anti-inflammatory, antioxidative, and antiapoptotic effects. In this review, we will summarize the recent publications of the pharmacological effects of these five groups of compounds. Understanding the mechanisms of action of these compounds may provide new treatment opportunities for the patients with neurodegenerative diseases.

\section{Introduction}

1.1. Neurodegenerative Diseases. Neurodegenerative diseases are associated with high morbidity, mortality, and economic burden to the community worldwide. It is estimated to have 22 million people worldwide suffering from these diseases and this number is expected to be triple in western countries by 2050 due to the increase in average life expectancy [1]. The diseases can be categorized as acute (including stroke, brain trauma, and spinal cord injury) and chronic (including amyotrophic lateral sclerosis (ALS), Huntington's disease, Alzheimer's disease (AD), and Parkinson's disease (PD)) diseases, which are characterized by selective loss of neuronal systems. Increasing evidence shows that neurodegenerative diseases are mediated by neuroinflammation, oxidative stress, and apoptotic cell death $[2,3]$.
1.1.1. Role of Neuroinflammation in Neurodegenerative Diseases. Neuroinflammation is the reaction of the endogenous central nervous system (CNS) in response to various pathologic events. Upon stimulation, microglia, the resident tissue macrophages, are firstly activated to represent the first line of defense [4] by releasing proinflammatory mediators including cytokines, chemokines, proteases, and reactive oxygen species (ROS)/reactive nitrogen species [57]. Indeed, microglial activation is beneficial to the CNS as it controls infection, minimizes further injury, and promotes repair. Under other circumstances, however, irresolvable stimuli can cause highly detrimental effects to neurons by the excess productions of proinflammatory mediators including interleukin-1 (IL-1), IL-6, nitric oxide, monocyte chemotactic protein-1 (MCP-1), prostaglandins, and tumor necrosis factor- $\alpha$ (TNF- $\alpha$ ) by microglial cells $[8,9]$. The stimuli that 
cause microglial overactivation can be diverse, ranging from endotoxin (e.g., lipopolysaccharide (LPS)) and neurotoxin (e.g., amyloid- $\beta(\mathrm{A} \beta)$ ) to neuronal death. $\mathrm{A} \beta$, implicated in pathogenesis of $\mathrm{AD}$, activates microglia to release neurotoxic factors such as nitric oxide [10] and TNF [11].

Interleukin-1 (IL-1), existing in two distinct isoforms, IL$1 \alpha$ and IL- $1 \beta$, is one of the most widely studied proinflammatory cytokines in the brain. It is partly due to the elevated IL1 expression detected in patients with acute or chronic neurodegenerative diseases [12]. Upon CNS damage/infection, microglial cells produce the highest levels of IL-1 [13]. In turn, IL-1 activates microglial and endothelial cells to produce various kinds of mediators including proinflammatory cytokines (IL-6 and TNF- $\alpha$ ), chemokines (MCP-1), adhesion molecules, prostaglandins, ROS, nitric oxide, and matrix metalloproteases, which are considered to be toxic to neurons and glial cells [14].

Tumor necrosis factor- $\alpha$ (TNF- $\alpha$ ) is another major mediator known to be implicated in several neurodegenerative diseases including AD, ALS, PD, and stroke [15]. In the CNS, elevated TNF- $\alpha$ is synthesized by astrocytes, neurons, and microglia upon infections/injuries [16]. TNF- $\alpha$ is found to mediate its effect via its receptor TNF-R1 which augments neuronal death through induction of caspases signalings [17]. Moreover, TNF- $\alpha$ can induce the productions of IL- 1 and IL-6, which can amplify the neuroinflammation process.

Endotoxin and neurotoxin-induced proinflammatory cytokines productions have been regulated by three wellknown mitogen-activated protein kinases (MAPKs) including extracellular signal-regulated kinase (ERK), p38, and cJun N-terminal kinase/stress-activated protein kinase (JNK) $[18,19]$. MAPKs transduce the extracellular stimuli through a cascade of protein phosphorylations, which leads to the activation of transcription factor nuclear factor $(\mathrm{NF})-\kappa \mathrm{B}$. The activated NF- $\kappa \mathrm{B}$ is then translocated and bound to $\kappa \mathrm{B}$ binding sites in the nucleus, leading to the initiation of transcription of proinflammatory mediators.

1.1.2. Role of Oxidative Stress in Neurodegenerative Diseases. Oxidative stress refers to the imbalance between the production of ROS and the ability of the cells to eliminate them [20]. Numerous studies have provided evidence that ROS are directly involved in oxidative damage of cellular macromolecules, resulting in neuronal cell death [21]. ROS including hydrogen peroxide, nitric oxide, superoxide anion, and the highly reactive hydroxyl radicals are produced by microglia in response to the stimulation by endotoxin (e.g., LPS) [22], neurotoxin (e.g., A $\beta$ and 6-hydroxydopamine (6OHDA) $[23,24]$, and environmental toxins (e.g., Rotenone) [25]. From which, nitric oxide can react with superoxide anion to form extremely reactive peroxynitrite, which can indiscriminately damage neurons by promoting membrane lipid peroxidation and by the formation of nitrotyrosine [26]. Furthermore, it stimulates the release of apoptosis-inducing factor (AIF) from the mitochondria, which subsequently triggers DNA fragmentation processes [27]. Enzymatic antioxidants including superoxide dismutase (SOD) and catalase (CAT) have been found to catalyze the dismutation of the superoxide anion and breakdown of hydrogen peroxide, respectively [28].

1.1.3. Cell Death Mechanisms. Increasing lines of evidence indicate that neuronal cell death that occurred in various neurodegenerative disorders is mediated by necrosis and apoptosis [29]. Necrosis is a form of traumatic cell death by cytoplasmic swelling, nuclear dissolution, and lysis, while apoptosis is an orderly and compartmental dismantling of cells. In acute neurodegenerative diseases, like ischemic stroke, cells undergo necrosis in the core region of the ischemic infarct when their intracellular supply of metabolic substrates (e.g., glucose and oxygen) is depleted. The process triggers the generation of free radicals, glutamate, cytotoxic cytokines, and massive calcium influx through $N$-methyl-D-aspartate (NMDA) receptors and voltage-dependent calcium channels [30]. The calcium influx and ROS generation trigger the pathogenesis of apoptosis [31]. It is executed by caspases and regulated by the $\mathrm{Bcl}-2$ protein family [32]. Caspases are considered as the major executioners of the apoptotic pathway [32]. Caspases-3, -6 , and -7 are short prodomain caspases predominantly activated through the action by other proteases. Activated caspase-3 can cleave the DNA repair enzyme poly(ADP-ribose) polymerase (PARP), which can cause abrogation of DNA repair and depletion of $\mathrm{NAD}^{+}$and ATP, resulting in cell death [33]. Apoptosis is also regulated by the Bcl-2 family of proteins [34], from which gene expressions are activated including pro- (Bad and Bax) and anti- (Bcl2 and $\mathrm{Bcl}-\mathrm{xL}$ ) apoptotic proteins. In response to apoptotic stimuli, Bad and Bax translocate to mitochondria to initiate the release of cytochrome $c$, which is able to trigger the apoptotic signaling cascade by activating the caspase- 9 and caspase-3, resulting in nuclear fragmentation and cell death [32]. In contrast, antiapoptotic proteins including $\mathrm{Bcl}-2$ and $\mathrm{Bcl}-\mathrm{xL}$ function as repressors of cell death in the CNS due to their abilities to block the release of cytochrome $\mathrm{c}$ suppress the accumulation of ROS [35].

\subsection{TCM as an Alternative Medicine for Neurodegenerative} Disease. Nowadays, there are no therapeutic drugs that can cure $\mathrm{AD}$ and $\mathrm{PD}$ due to the incomplete understanding of their pathogenic mechanisms. Current clinical practices to treat $\mathrm{AD}$ include the usage of cholinesterase inhibitors and glutamate modulators [36]. In addition, other approaches including anti-inflammatory, antioxidative, and anti-A $\beta$ peptides agents have been used to mitigate the symptoms of $\mathrm{AD}$ [37]. Recent therapies for PD are based mainly on three strategies: (1) the usage of L-DOPA for compensating the progressive degeneration of dopaminergic neurons in the substantia nigra pars compacta [38]; (2) the identification of non-dopaminergic drugs for alleviating nonmotor symptoms; and (3) the development of neuroprotective and disease-modifying compounds $[39,40]$. Most of these clinical therapies on slowing down the progression of symptoms of the neurodegenerative diseases are still in the preclinical phase and only a few of them are in the clinical phase. However, the efficacies of the treatments are not considered as satisfactory [1]. For the treatment of acute ischemic stroke, 


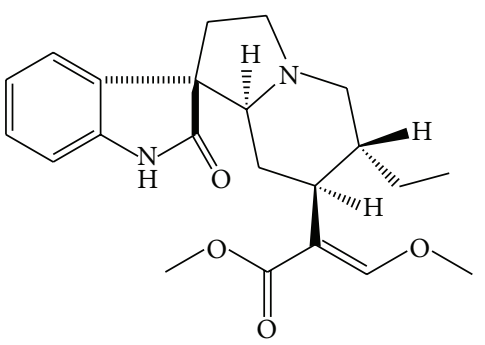

(1)

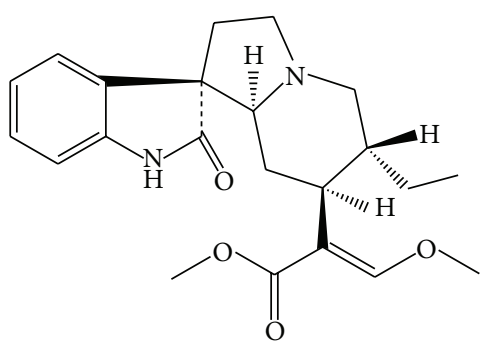

(2)<smiles>COc1cc(C(=O)OCCCCN=C(N)N)cc(OC)c1O</smiles>

(3)

FIGURE 1: Chemical structure of alkaloids: (1) rhynchophylline; (2) isorhynchophylline; (3) leonurine.

thrombolytic agent such as recombinant tissue-plasminogen activator is available for the patients. However, the treatments are limited by a short therapeutic window of time and side effects [41]. At present, there is no effective clinical treatment that can enhance the recovery or prevent the recurrence of stroke. It is, therefore, critical to identify the pharmacological agents that can alleviate the neurodegenerative syndromes with fewer side effects compared with the current therapies.

Traditional Chinese medicine (TCM) has been practiced in health care systems for thousands of years in China. A variety of studies have demonstrated that the herbal formulations, herbal extracts, and active compounds derived from Chinese herbs are effective on the in vitro and in vivo neurodegenerative models $[42,43]$. Since the pathogenesis of neurodegenerative diseases can not be single factor-derived, a combination of different herbs as herbal decoction could be an effective therapeutic approach. Herbal decoction consists of multiple crude herbs may work on multiple targets to enhance the therapeutic effects synergistically [40].

1.3. Pharmacological Effects of Gastrodia and Uncaria Decoction (GUD) on Neurodegenerative Disease. Gastrodia and Uncaria Decoction (GUD) is often used in TCM prescriptions for stroke treatment in China. It was first described in TCM book for clinical diagnosis and therapy, titled "New Significance of Patterns and Treatment in Miscellaneous Diseases." There are 11 herbs in this decoction, including Rhizoma Gastrodiae (Tian Ma), Ramulus cum Uncis Uncariae (Gou Teng), Concha Haliotidis (Shi Jue Ming), Fructus Gardeniae (Zhi Zi), Radix Scutellariae (Huang Qin), Eucommia ulmoides Oliver (Du Zhong), Radix Cyathulae Officinalis (Niu Xi), Ramulus Loranthi (Sang Ji Sheng), Poria cum Radix Pini (Fu Sheng), Caulis Polygoni Multiflori (Ye Jiao Teng), and Herba Leonuri (Yi Mu Cao). For the stroke treatment, the pharmacological effects of the decoction are (1) to subdue the liver and extinguish internal wind (Tian Ma, Gou Teng, and Shi Jue Ming); (2) to entice the blood downward (Niu Xi); (3) to purge liver fire (Huang Qin and Zhi Zi); (4) to supplement liver and kidney (Sang Ji Sheng and Du Zhong); (5) to vitalize the blood and enhance water metabolism (Yi Mu Cao); and (6) to pacify the restless heart (Ye Jiao Teng and Fu Sheng) [44].

In addition, a study revealed that GUD significantly prevented hypertension in spontaneously hypertensive rats (SHR) model and altered the development of hypertension [45]. Another study reported that the serum of GUD-treated rat inhibited the proliferation of vascular smooth muscle cells (VSMCs) by suppressing the expressions of proliferating cell nuclear antigen (PCNA) and c-myc, increasing nitric oxide and decreasing endothelin-1 (ET-1) levels [46].

Neurodegenerative disorders and stroke share many pathogenic mechanisms such as inflammation, microglial activation, oxidative stress, impaired neurotransmission, mitochondrial dysfunction, and apoptosis [47, 48]. Neuroprotective agents that interfere with the biochemical cascades would be the potential therapeutic candidates. Thus, the combination of different active compounds from individual herb aiming at specific pathological factors would be the systematic approach for the treatment of neurodegenerative diseases. In this review, the anti-inflammatory, antioxidative, and antiapoptotic effects of some of the active pharmacological compounds (Figures 1, 2, 3, 4, and 5) identified from individual herb of GUD will be summarized (Table 1 and Figure 6).

\section{Alkaloids}

Alkaloids, a group of naturally occurring compounds originated from plant and microbes, contain at least one nitrogen atom in the structure. The functions of alkaloids are well known to protect the plants from predators and regulate plant 
<smiles>Oc1cc(O)c2c(c1)OC(c1ccc(O)c(O)c1)C(O)C2</smiles>

$(4)$<smiles>[R20]Oc1c([R])c(O)c2c(=O)c([R3])c(-c3cc([R6])c([R5])c([R])c3)oc2c1[R]</smiles>

(5) Quercetin: $\mathrm{R}_{1}=\mathrm{H} ; \mathrm{R}_{2}=\mathrm{H} ; \mathrm{R}_{3}=\mathrm{OH} ; \mathrm{R}_{4}=\mathrm{OH} ; \mathrm{R}_{5}=\mathrm{OH} ; \mathrm{R}_{6}=\mathrm{H} ; \mathrm{R}_{7}=\mathrm{H}$

(6) Rutin: $\mathrm{R}_{1}=\mathrm{H} ; \mathrm{R}_{2}=\mathrm{H} ; \mathrm{R}_{3}=\mathrm{O}$-disaccharide rutinose; $\mathrm{R}_{4}=\mathrm{OH} ; \mathrm{R}_{5}=\mathrm{OH} ; \mathrm{R}_{6}=\mathrm{H} ; \mathrm{R}_{7}=\mathrm{H}$

(7) Baicalein: $\mathrm{R}_{1}=\mathrm{H} ; \mathrm{R}_{2}=\mathrm{OH} ; \mathrm{R}_{3}=\mathrm{H} ; \mathrm{R}_{4}=\mathrm{H} ; \mathrm{R}_{5}=\mathrm{H} ; \mathrm{R}_{6}=\mathrm{H} ; \mathrm{R}_{7}=\mathrm{H}$

(8) Baicalin: R1 = glucuronide; $\mathrm{R}_{2}=\mathrm{OH} ; \mathrm{R}_{3}=\mathrm{H} ; \mathrm{R}_{4}=\mathrm{H} ; \mathrm{R}_{5}=\mathrm{H} ; \mathrm{R}_{6}=\mathrm{H} ; \mathrm{R}_{7}=\mathrm{H}$

(9) Wogonin: $\mathrm{R}_{1}=\mathrm{H} ; \mathrm{R}_{2}=\mathrm{H} ; \mathrm{R}_{3}=\mathrm{H} ; \mathrm{R}_{4}=\mathrm{H} ; \mathrm{R}_{5}=\mathrm{H} ; \mathrm{R}_{6}=\mathrm{H} ; \mathrm{R}_{7}=\mathrm{OCH}_{3}$

(10) Oroxylin A: $\mathrm{R}_{1}=\mathrm{H} ; \mathrm{R}_{2}=\mathrm{OCH}_{3} ; \mathrm{R}_{3}=\mathrm{H} ; \mathrm{R}_{4}=\mathrm{H} ; \mathrm{R}_{5}=\mathrm{H} ; \mathrm{R}_{6}=\mathrm{H} ; \mathrm{R}_{7}=\mathrm{H}$

(11) Apigenin: $\mathrm{R}_{1}=\mathrm{H} ; \mathrm{R}_{2}=\mathrm{H} ; \mathrm{R}_{3}=\mathrm{H} ; \mathrm{R}_{4}=\mathrm{H} ; \mathrm{R}_{5}=\mathrm{OH} ; \mathrm{R}_{6}=\mathrm{H} ; \mathrm{R}_{7}=\mathrm{H}$

(12) Kaempferol: $\mathrm{R}_{1}=\mathrm{H} ; \mathrm{R}_{2}=\mathrm{H} ; \mathrm{R}_{3}=\mathrm{OH} ; \mathrm{R}_{4}=\mathrm{H} ; \mathrm{R}_{5}=\mathrm{OH} ; \mathrm{R}_{6}=\mathrm{H} ; \mathrm{R}_{7}=\mathrm{H}$

(13) Hyperoside: $\mathrm{R}_{1}=\mathrm{H} ; \mathrm{R}_{2}=\mathrm{H} ; \mathrm{R}_{3}=\mathrm{O}$-galactoside; $\mathrm{R}_{4}=\mathrm{H} ; \mathrm{R}_{5}=\mathrm{OH} ; \mathrm{R}_{6}=\mathrm{OH} ; \mathrm{R}_{7}=\mathrm{H}$

Figure 2: Chemical structure of flavonoids: (4) catechin; (5) quercetin; (6) rutin; (7) baicalein; (8) baicalin; (9) wogonin; (10) oroxylin A; (11) apigenin; (12) kaempferol; (13) hyperoside.

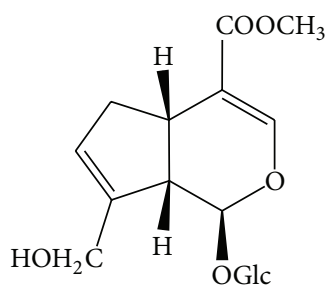

(13)

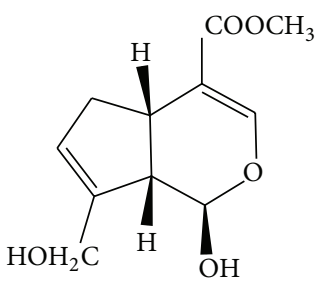

(14)

FIGURE 3: Chemical structure of iridoids: (13) geniposide and (14) genipin.<smiles>CC(=C/C=C/C(C)=C/C=C/C=C(C)/C=C/C=C(\C)C(=O)O)C(=O)O</smiles>

(15)

FIGURE 4: Chemical structure of carotenoid: (15) crocetin.

growth. Its pharmacological activities have been documented to be anticancer [49], anti-inflammatory [50], and cardiovascular effects [51].<smiles>OCc1ccc(OC2OC(O)C3C(O)CC(O)C(O)C3O2)cc1</smiles>

Figure 5: Chemical structure of phenolic compounds: (16) gastrodin and (17) p-Hydroxybenzyl alcohol.

2.1. Rhynchophylline and Isorhynchophylline. Rhynchophylline and isorhynchophylline are the two most dominant alkaloid constituents in Ramulus cum Uncis Uncariae [52, 53]. Their pharmacological activities were extensively studied which have been shown to exert anti-inflammatory [54-56], antioxidative $[57,58]$, and neuroprotective $[57,59-64]$ effects in CNS. Anti-inflammatory effects of rhynchophylline and isorhynchophylline were found in primary cultured rat cortical microglia. One of the investigations showed that both rhynchophylline and isorhynchophylline reduced the production of nitric oxide in LPS-induced rat cortical microglia [54]. More recently, another study investigated the action of rhynchophylline on the productions of proinflammatory 
TABLE 1: Summary of the effects of different bioactive compounds in GUD on neurodegenerative diseases.

(a)

\begin{tabular}{|c|c|c|c|}
\hline \multicolumn{4}{|c|}{ Alkaloids } \\
\hline Rhynchophylline & In vitro/ex vivo & & \\
\hline Cells used (in vitro) & Inducer(s) & Functions & References \\
\hline Xenopus oocytes & Glutamate & Inhibitory effects on NMDA receptors & {$[60]$} \\
\hline $\begin{array}{l}\text { Hippocampal slices } \\
\text { Xenopus oocytes }\end{array}$ & $\begin{array}{l}\text { Deprivation of } \\
\text { oxygen and glucose }\end{array}$ & $\begin{array}{l}\downarrow \text { neuronal damage } \\
\text { Inhibitory effects on NMDA, muscarinic } \mathrm{M}_{1} \text {, and } 5-\mathrm{HT}_{2} \\
\text { receptors-mediated neurotoxicity }\end{array}$ & {$[62]$} \\
\hline Rat cortical microglia & LPS & $\downarrow$ nitric oxide production & {$[54]$} \\
\hline Mouse N9 microglia & LPS & $\begin{array}{l}\downarrow \text { TNF- } \alpha \text {, IL1- } \beta \text {, and nitric oxide productions } \\
\downarrow \text { ERK and p38 phosphorylations, } I \kappa \mathrm{B} \alpha \text { degradation, and } \\
\text { iNOS protein level }\end{array}$ & {$[55]$} \\
\hline Rat primary microglia & LPS & $\begin{array}{l}\downarrow \text { iNOS and COX- } 2 \text { mRNA levels } \\
\downarrow \text { nitric oxide, PGE } 2, \text { MCP- } 1 \text {, TNF- } \alpha \text {, and } \\
\text { IL1- } \beta \text { productions } \\
\downarrow \text { ERK and p38 phosphorylations and } \mathrm{I} \kappa \mathrm{B} \alpha \text { degradation }\end{array}$ & {$[56]$} \\
\hline NT2 cells & Dopamine & $\downarrow$ apoptosis & {$[61]$} \\
\hline Rat primary cortical neurons & Methamphetamine & $\downarrow$ neurotoxicity & {$[63]$} \\
\hline Rat cerebellar granule cells & Glutamate & $\uparrow$ cell viability by inhibition of $\mathrm{Ca}^{2+}$ influx & {$[59]$} \\
\hline Rhynchophylline & In vivo & & \\
\hline Type of animals (in vivo) & $\begin{array}{l}\text { Disease model used } \\
\text { (in vivo) }\end{array}$ & Functions & References \\
\hline Rats & $\begin{array}{l}\text { Kainic acid-induced } \\
\text { epileptic seizures }\end{array}$ & $\begin{array}{l}\downarrow \text { superoxide anions level, JNK phosphorylation, and } \\
\text { NF- } \kappa \text { B activation }\end{array}$ & {$[57]$} \\
\hline Isorhynchophylline & In vitro/ex vivo & & \\
\hline Cells used (in vitro) & Inducer(s) & Functions & References \\
\hline Xenopus oocytes & Glutamate & $\begin{array}{l}\text { Inhibitory effects on NMDA receptors by acting as } \\
\text { noncompetitive antagonists }\end{array}$ & {$[60]$} \\
\hline $\begin{array}{l}\text { Hippocampal slices } \\
\text { Xenopus oocytes }\end{array}$ & $\begin{array}{l}\text { Deprivation of } \\
\text { oxygen and glucose }\end{array}$ & $\begin{array}{l}\downarrow \text { neuronal damage } \\
\text { Inhibitory effects on NMDA, muscarinic } \mathrm{M}_{1} \text {, and 5- } \mathrm{HT}_{2} \\
\text { receptors-mediated neurotoxicity }\end{array}$ & {$[62]$} \\
\hline $\begin{array}{l}\text { N2a, SH-SY5Y, PC12 cells, and } \\
\text { primary cortical neurons } \\
\text { Differentiated human } \\
\text { dopaminergic neurons }\end{array}$ & Nil & $\begin{array}{l}\text { Stimulate autophagy of wild-type, A53T and A30P } \alpha \text {-syn } \\
\text { monomers, } \alpha \text {-syn oligomers, and } \alpha \text {-syn/synphilin- } 1 \\
\text { aggresomes } \\
\downarrow \text { wild-type and A53T } \alpha \text {-syn protein expressions }\end{array}$ & {$[64]$} \\
\hline Rat cortical microglia & LPS & $\downarrow$ nitric oxide production & {$[54]$} \\
\hline Mouse N9 microglia & LPS & $\begin{array}{l}\downarrow \text { TNF- } \alpha \text {, IL1- } \beta \text {, and nitric oxide productions } \\
\downarrow \text { ERK and p38 phosphorylations, } I \kappa \mathrm{B} \alpha \text { degradation, and } \\
\text { iNOS protein level }\end{array}$ & {$[55]$} \\
\hline PC12 cells & $\mathrm{A} \beta_{(25-35)}$ & $\begin{array}{l}\uparrow \text { cell viability and GSH level } \\
\downarrow \text { intracellular ROS and MDA levels } \\
\downarrow \text { DNA fragmentation and caspase- } 3 \text { activity } \\
\text { Stabilize mitochondrial membrane potential } \\
\text { Moderate Bcl-2/Bax ratio }\end{array}$ & {$[58]$} \\
\hline Rat cerebellar granule cells & Glutamate & $\uparrow$ cell viability by inhibition of $\mathrm{Ca}^{2+}$ influx & {$[59]$} \\
\hline Leonurine & In vitro/ex vivo & & \\
\hline Cells used (in vitro) & Inducer(s) & Functions & References \\
\hline SH-SY5Y cells & 6-OHDA & $\begin{array}{l}\downarrow \text { cell death, ROS level, and Bax expression } \\
\uparrow \text { superoxide dismutase activity and Bcl-2 expression }\end{array}$ & [67] \\
\hline
\end{tabular}


(a) Continued.

\begin{tabular}{|c|c|c|c|}
\hline \multicolumn{4}{|c|}{ Alkaloids } \\
\hline Leonurine & In vivo & & \\
\hline Type of animals (in vivo) & $\begin{array}{l}\text { Disease model used } \\
\text { (in vivo) }\end{array}$ & Functions & References \\
\hline Rats & MCAO & $\begin{array}{l}\downarrow \text { ROS level and Bax expression } \\
\uparrow \text { Bcl-2 expression }\end{array}$ & {$[68]$} \\
\hline Rats & MCAO & $\begin{array}{l}\downarrow \text { infarct volume and lipid peroxidation } \\
\uparrow \text { superoxide dismutase and glutathione peroxidase }\end{array}$ & {$[69]$} \\
\hline & & (b) & \\
\hline \multicolumn{4}{|c|}{ Flavonoids } \\
\hline Catechin & In vitro/ex vivo & & \\
\hline Cells used (in vitro) & Inducer(s) & Functions & References \\
\hline Rat cerebellar granule cells & Glutamate & $\uparrow$ cell viability by inhibition of $\mathrm{Ca}^{2+}$ influx & {$[78]$} \\
\hline $\begin{array}{l}\text { Rat primary mesencephalic } \\
\text { cultures }\end{array}$ & $\begin{array}{l}\mathrm{MPP}^{+} \\
\mathrm{H}_{2} \mathrm{O}_{2}, 4-\mathrm{HNE} \\
\text { rotenone, and } \\
6 \text {-OHDA }\end{array}$ & $\begin{array}{l}\downarrow \text { apoptosis } \\
\uparrow \text { cellular viability and }\left[{ }^{3} \mathrm{H}\right] \text { DA uptake }\end{array}$ & {$[75]$} \\
\hline Catechin & In vivo & & \\
\hline Type of animals (in vivo) & $\begin{array}{l}\text { Disease model used } \\
\text { (in vivo) }\end{array}$ & Functions & References \\
\hline Rats & Nil & $\downarrow$ MOA-B activity & [74] \\
\hline Quercetin & In vitro/ex vivo & & \\
\hline Cells used (in vitro) & Inducer(s) & Functions & References \\
\hline $\begin{array}{l}\text { N9 microglia } \\
\text { PC12 cells }\end{array}$ & $\begin{array}{l}\text { LPS } \\
\text { LPS-induced N9 } \\
\text { microglia cells }\end{array}$ & $\begin{array}{l}\downarrow \text { TNF- } \alpha \text { and IL- } 1 \alpha \text { mRNA levels } \\
\downarrow \text { apoptosis and cell death }\end{array}$ & {$[72]$} \\
\hline PC12 cells & 6-OHDA & $\begin{array}{l}\downarrow \text { apoptosis and cell death } \\
\downarrow \text { nitric oxide overproduction and iNOS overexpression }\end{array}$ & {$[73]$} \\
\hline $\begin{array}{l}\text { Rat primary mesencephalic } \\
\text { cultures }\end{array}$ & $\mathrm{MPP}^{+}$ & $\downarrow$ apoptosis & {$[75]$} \\
\hline Rat cortical neuronal cultures & $\mathrm{A} \beta_{(1-42)}$ & $\downarrow$ cytotoxicity, protein oxidation, lipid peroxidation, and apoptosis & [79] \\
\hline PC12 cells & $\mathrm{MPP}^{+}$ & $\begin{array}{l}\downarrow \text { apoptosis and cell death } \\
\downarrow \text { Bax and } \uparrow \text { Bcl-2 expressions } \\
\downarrow \text { AIF in cytosolic and nuclear fraction } \\
\downarrow \text { cytochrome c levels in cytosolic fraction }\end{array}$ & {$[80]$} \\
\hline P19 neurons & $\mathrm{H}_{2} \mathrm{O}_{2}$ & $\begin{array}{l}\uparrow \text { neuronal viability } \\
\downarrow \text { ROS production } \\
\downarrow \text { nuclear condensation, caspase } 3 / 7 \text { activity, and PARP } \\
\text { upregulation }\end{array}$ & {$[76]$} \\
\hline SH-SY5Y cells & $\mathrm{H}_{2} \mathrm{O}_{2}$ & $\begin{array}{l}\downarrow \text { cytotoxicity and } \mathrm{LDH} \text { release } \\
\downarrow \text { Bax and } \uparrow \mathrm{Bcl}-2 \text { expressions } \\
\downarrow \text { caspase activation }\end{array}$ & [81] \\
\hline Quercetin & In vivo & & \\
\hline Type of animals (in vivo) & $\begin{array}{l}\text { Disease model used } \\
\text { (in vivo) }\end{array}$ & Functions & References \\
\hline Zebra fish & $6-\mathrm{OHDA}$ & $\begin{array}{l}\downarrow \text { dopaminergic neuron loss } \\
\downarrow \text { TNF- } \alpha \text {, IL- } 1 \beta \text {, and COX-2 overexpressions }\end{array}$ & {$[73]$} \\
\hline Rats & 6-OHDA & $\begin{array}{l}\uparrow \text { striatal dopamine and antioxidant enzyme levels } \\
\downarrow \text { protein carbonyl content in the striatum } \\
\uparrow \text { neuronal survivability }\end{array}$ & {$[77]$} \\
\hline Rats & $\begin{array}{l}\text { Repeated cerebral } \\
\text { ischemia }\end{array}$ & $\begin{array}{l}\text { Improve spatial memory impairment } \\
\downarrow \text { neuronal death }\end{array}$ & {$[82]$} \\
\hline Rats & pMCAO & $\begin{array}{l}\downarrow \text { ischemic lesion } \\
\uparrow \text { GSH levels in ipsilateral striatum and cortex }\end{array}$ & {$[83]$} \\
\hline
\end{tabular}


(b) Continued.

\begin{tabular}{|c|c|c|c|}
\hline \multicolumn{4}{|c|}{ Flavonoids } \\
\hline Rutin & In vitro/ex vivo & & \\
\hline Cells used (in vitro) & Inducer(s) & Functions & References \\
\hline RAW 264.7 cells & LPS & $\begin{array}{l}\downarrow \text { nitric oxide production } \\
\downarrow \text { iNOS gene expression }\end{array}$ & [89] \\
\hline $\begin{array}{l}\text { SH-SY5Y cells } \\
\text { BV-2 microglia }\end{array}$ & $\mathrm{A} \beta_{42}$ & $\begin{array}{l}\downarrow \text { ROS production } \\
\downarrow \text { TNF- } \alpha \text { and IL- } 1 \beta \text { productions }\end{array}$ & {$[90]$} \\
\hline Rutin & In vivo & & \\
\hline Type of animals (in vivo) & $\begin{array}{l}\text { Disease model used } \\
\text { (in vivo) }\end{array}$ & Functions & References \\
\hline Rats & 6-OHDA & $\begin{array}{l}\uparrow \text { antioxidant enzymes activities } \\
\downarrow \text { nitric oxide level }\end{array}$ & {$[91]$} \\
\hline Rats & Trimethyltin (TMT) & $\downarrow$ IL- $1 \beta$ and IL-6 mRNA levels & {$[92]$} \\
\hline Rats & Cerebral ischemia & $\downarrow$ neuronal death & {$[93]$} \\
\hline Baicalein & In vitro/ex vivo & & \\
\hline Cells used (in vitro) & Inducer(s) & Functions & References \\
\hline BV-2 microglia & Hypoxia & $\begin{array}{l}\downarrow \text { HIF-1 protein accumulation and transcriptional activation } \\
\downarrow \text { iNOS, COX-2, and VEGF gene expressions }\end{array}$ & {$[97]$} \\
\hline $\begin{array}{l}\text { Primary midbrain } \\
\text { neuron-glia cultures }\end{array}$ & LPS & $\downarrow$ TNF- $\alpha$, nitric oxide, and superoxide productions & [94] \\
\hline SH-SY5Y cells & 6-OHDA & $\begin{array}{l}\downarrow \text { oxidative stress, mitochondrial dysfunction, caspase activity, and } \\
\text { JNK activation }\end{array}$ & {$[99]$} \\
\hline SH-SY5Y cells & 6-OHDA & $\downarrow$ apoptosis & {$[100]$} \\
\hline $\begin{array}{l}\text { HT22 mouse hippocampal } \\
\text { neuronal cells }\end{array}$ & $\begin{array}{l}\text { Thapsigargin (TG) } \\
\text { and brefeldin A (BFA) }\end{array}$ & $\begin{array}{l}\downarrow \text { apoptosis } \\
\downarrow \text { C/EBP homologous protein (CHOP) induction and ROS } \\
\text { accumulation }\end{array}$ & {$[101]$} \\
\hline Rat glioma C6 cells & $\mathrm{H}_{2} \mathrm{O}_{2}$ & $\begin{array}{l}\downarrow \text { ROS-mediated cytotoxic effects } \\
\text { Modulate ERKs activation } \\
\uparrow \text { HO-1 protein expression }\end{array}$ & {$[102]$} \\
\hline Primary microglia/BV-2 cells & LPS/IFN- $\gamma$ & $\begin{array}{l}\downarrow \text { nitric oxide production and iNOS gene expression } \\
\downarrow \text { NF-IL6 binding }\end{array}$ & {$[98]$} \\
\hline PC12 cells & Rotenone & $\begin{array}{l}\downarrow \text { apoptosis } \\
\downarrow \text { ROS production }\end{array}$ & {$[103]$} \\
\hline Baicalein & In vivo & & \\
\hline Type of animals (in vivo) & $\begin{array}{l}\text { Disease model used } \\
\text { (in vivo) }\end{array}$ & Functions & References \\
\hline Rats & $\begin{array}{l}\text { Controlled cortical } \\
\text { impact injury }\end{array}$ & $\begin{array}{l}\text { Improve functional recovery } \\
\downarrow \text { contusion volumes } \\
\downarrow \text { the number of degenerating neurons } \\
\downarrow \text { TNF- } \alpha \text {, IL- } 1 \beta \text {, and IL- } 6 \text { mRNA and protein levels }\end{array}$ & {$[104]$} \\
\hline Baicalin & In vitro/ex vivo & & \\
\hline Cells used (in vitro) & Inducer(s) & Functions & References \\
\hline RAW 264.7 cells & LPS & $\begin{array}{l}\downarrow \text { nitric oxide production } \\
\downarrow \text { iNOS and COX-2 gene expressions }\end{array}$ & {$[118]$} \\
\hline $\begin{array}{l}\text { RAW } 264.7 \text { cells and peritoneal } \\
\text { macrophages }\end{array}$ & LPS or IFN- $\gamma$ & $\begin{array}{l}\downarrow \text { nitric oxide production and iNOS expression } \\
\downarrow \text { TNF- } \alpha \text {, ET-1, and thromboxane A2 (TXA2) }\end{array}$ & {$[106]$} \\
\hline PC12 cells & $\begin{array}{l}\text { Oxygen-glucose } \\
\text { deprivation } / \mathrm{H}_{2} \mathrm{O}_{2}\end{array}$ & $\begin{array}{l}\downarrow \text { ROS production } \\
\downarrow 5 \text {-LOX nuclear translocation } \\
\downarrow \text { p38 phosphorylation }\end{array}$ & [107] \\
\hline Baicalin & In vivo & & \\
\hline Type of animals (in vivo) & $\begin{array}{l}\text { Disease model used } \\
\text { (in vivo) }\end{array}$ & Functions & References \\
\hline Rats & pMCAO & $\begin{array}{l}\downarrow \text { neurological deficit scores and cerebral infarct volume } \\
\downarrow \text { iNOS, COX- } 2 \text { mRNA, and cleaved caspase- } 3 \text { protein expressions } \\
\downarrow \text { TLR } 2 / 4 \text { and NF- } \kappa \text { B expressions }\end{array}$ & {$[108,109]$} \\
\hline
\end{tabular}


(b) Continued.

\begin{tabular}{|c|c|c|c|}
\hline \multicolumn{4}{|c|}{ Flavonoids } \\
\hline Rats & Spinal cord injury & $\begin{array}{l}\downarrow \text { oxidant stress, proinflammatory cytokines expressions, and } \\
\text { apoptosis }\end{array}$ & [111] \\
\hline Rats & $\begin{array}{l}\text { Focal cerebral } \\
\text { ischemic reperfusion } \\
\text { injury }\end{array}$ & $\downarrow$ NF- $\kappa$ B p65 level & {$[110]$} \\
\hline Wogonin & In vitro/ex vivo & & \\
\hline Cells used (in vitro) & Inducer(s) & Functions & References \\
\hline RAW 264.7 cells & LPS & $\begin{array}{l}\downarrow \mathrm{PGE}_{2} \text { and nitric oxide productions } \\
\downarrow \text { COX-2 expression and activity }\end{array}$ & {$[112-115]$} \\
\hline Microglia & LPS & $\begin{array}{l}\downarrow \text { nitric oxide production } \\
\downarrow \text { TNF- } \alpha \text { and IL- } 6 \text { productions } \\
\downarrow \text { NF- } \kappa \text { B activity }\end{array}$ & [116] \\
\hline Microglia & MCP-1 & $\downarrow$ NF- $\kappa$ B activity & [117] \\
\hline Wogonin & In vivo & & \\
\hline Type of animals (in vivo) & $\begin{array}{l}\text { Disease model used } \\
(\text { in vivo) }\end{array}$ & Functions & References \\
\hline Mice & LPS & $\begin{array}{l}\downarrow \text { nitric oxide production } \\
\downarrow \text { iNOS expression }\end{array}$ & [113] \\
\hline Rats & pMCAO & $\begin{array}{l}\downarrow \text { infarct volume } \\
\text { Improve behavioral dysfunction }\end{array}$ & [119] \\
\hline Oroxylin A & In vitro/ex vivo & & \\
\hline Cells used (in vitro) & Inducer(s) & Functions & References \\
\hline RAW 264.7 cells & LPS & $\begin{array}{l}\downarrow \text { nitric oxide production } \\
\downarrow \text { iNOS and COX- } 2 \text { gene expressions } \\
\downarrow \text { NF- } \kappa \text { B activation }\end{array}$ & {$[120]$} \\
\hline Apigenin & In vitro/ex vivo & & \\
\hline Cells used (in vitro) & Inducer(s) & Functions & References \\
\hline RAW 264.7 cells & LPS & $\begin{array}{l}\downarrow \text { COX- } 2 \text { and iNOS expressions } \\
\downarrow N F-\kappa B \text { activation }\end{array}$ & {$[123]$} \\
\hline PBMC & LPS & $\downarrow$ TNF- $\alpha$, IL- 6 , and IL- $1 \beta$ productions & {$[124]$} \\
\hline J774.2 macrophages & LPS & $\downarrow$ TNF- $\alpha$ and IL- $1 \beta$ mRNA levels & {$[125]$} \\
\hline BV-2 microglia & LPS & $\begin{array}{l}\downarrow \text { nitric oxide and } \mathrm{PGE}_{2} \text { productions } \\
\downarrow \text { p38 and JNK phosphorylations }\end{array}$ & [126] \\
\hline Apigenin & In vivo & & \\
\hline Type of animals (in vivo) & $\begin{array}{l}\text { Disease model used } \\
\text { (in vivo) }\end{array}$ & Functions & References \\
\hline Mice & MCAO & $\begin{array}{l}\downarrow \text { infarct volume } \\
\downarrow \text { the number of microglia }\end{array}$ & [126] \\
\hline Kaempferol & In vitro/ex vivo & & \\
\hline Cells used (in vitro) & Inducer(s) & Functions & References \\
\hline J774.2 macrophages & LPS & $\downarrow$ TNF- $\alpha$ and IL- $1 \beta$ mRNA levels & {$[125]$} \\
\hline J774 macrophages & LPS & $\begin{array}{l}\downarrow \mathrm{PGE}_{2} \text { production } \\
\downarrow \text { COX-2 and mPGES-1 mRNA levels }\end{array}$ & [127] \\
\hline J774 macrophages & LPS & $\begin{array}{l}\downarrow \text { nitric oxide production } \\
\downarrow \text { iNOS mRNA and protein expressions }\end{array}$ & [128] \\
\hline RAW 264.7 cells & LPS & $\downarrow$ nitric oxide, $\mathrm{PGE}_{2}$, and TNF- $\alpha$ productions & [129] \\
\hline Kaempferol & In vivo & & \\
\hline Type of animals (in vivo) & $\begin{array}{l}\text { Disease model used } \\
\text { (in vivo) }\end{array}$ & Functions & References \\
\hline Rats & $\begin{array}{l}\text { Transient focal } \\
\text { cerebral ischemia }\end{array}$ & $\begin{array}{l}\downarrow \text { nitrosative-oxidative stress, protein nitrotyrosines, and apoptotic } \\
\text { cell death }\end{array}$ & {$[130]$} \\
\hline
\end{tabular}


(b) Continued.

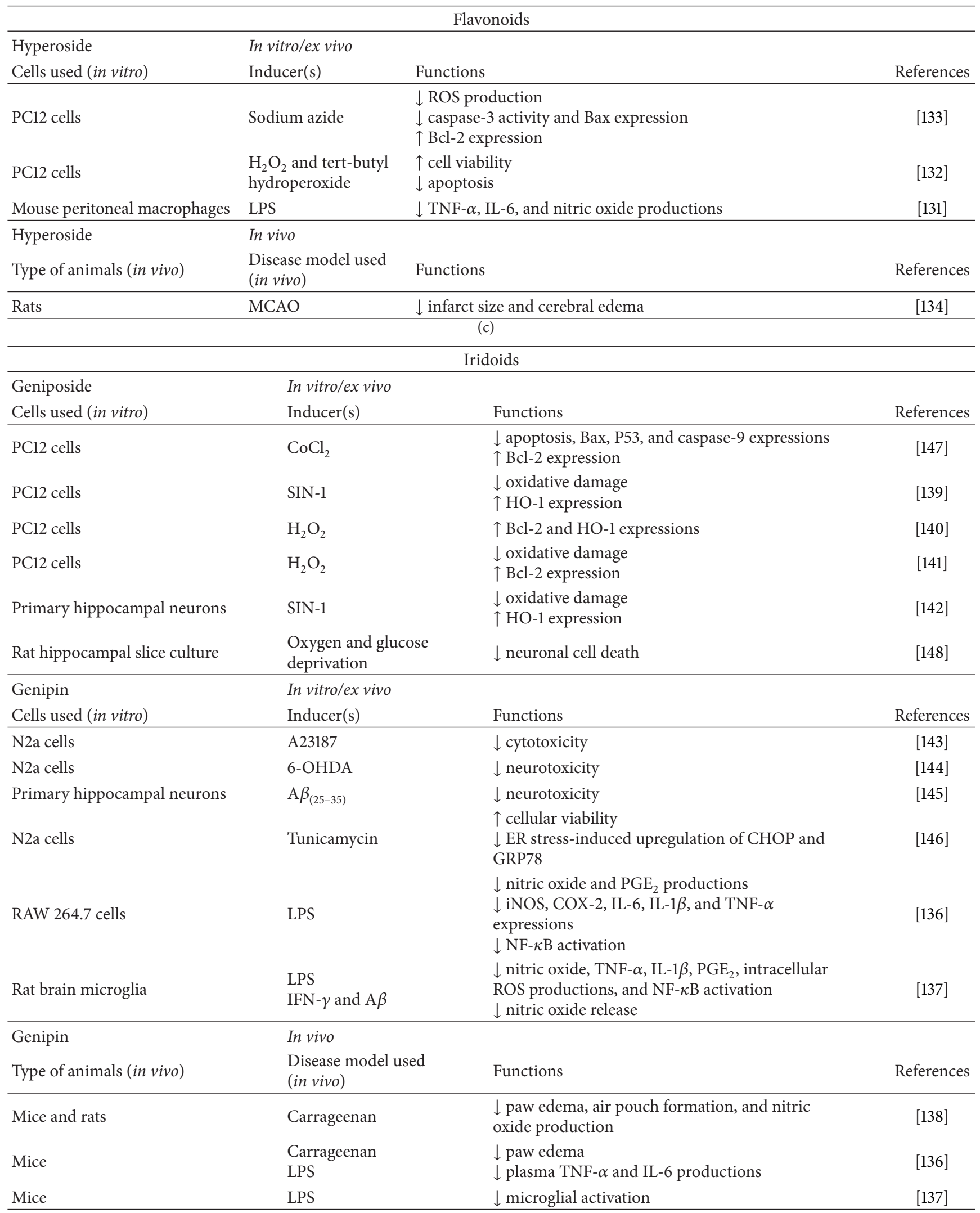


(d)

\begin{tabular}{|c|c|c|c|}
\hline \multicolumn{4}{|c|}{ Carotenoids } \\
\hline Crocetin & In vitro/ex vivo & & \\
\hline Cells used (in vitro) & Inducer(s) & Functions & References \\
\hline $\begin{array}{l}\text { Isolated brain of stroke-prone } \\
\text { spontaneously hypertensive rat }\end{array}$ & Nil & $\downarrow$ ROS-mediated oxidative stress & {$[157]$} \\
\hline SH-SY5Y cells & $\mathrm{H}_{2} \mathrm{O}_{2}$ & $\begin{array}{l}\uparrow \text { cellular viability } \\
\downarrow \text { ROS production and caspase- } 3 \text { activation }\end{array}$ & {$[158]$} \\
\hline Crocetin & In vivo & & \\
\hline Type of animals (in vivo) & $\begin{array}{l}\text { Disease model used } \\
\text { (in vivo) }\end{array}$ & Functions & References \\
\hline Rats & 6-OHDA & $\begin{array}{l}\uparrow \text { antioxidant activity, GSH, and dopamine levels } \\
\downarrow \text { TBARS level }\end{array}$ & [159] \\
\hline & & (e) & \\
\hline \multicolumn{4}{|c|}{ Natural phenols } \\
\hline Gastrodin & In vitro/ex vivo & & \\
\hline Cells used (in vitro) & Inducer(s) & Functions & References \\
\hline Cultured rat cortical neurons & Hypoxia & $\uparrow$ neuron survival & {$[160]$} \\
\hline $\begin{array}{l}\text { Cultured rat hippocampal } \\
\text { neurons }\end{array}$ & $\begin{array}{l}\text { Oxygen/glucose } \\
\text { deprivation and } \\
\text { glutamate }\end{array}$ & $\downarrow \mathrm{Ca}^{2+}$ and nitric oxide productions & {$[161]$} \\
\hline BV-2 cells & LPS & $\begin{array}{l}\downarrow \text { TNF- } \alpha \text { and IL- } 1 \beta \text { productions } \\
\downarrow \text { iNOS and COX- } 2 \text { expressions }\end{array}$ & {$[162]$} \\
\hline Gastrodin & In vivo & & \\
\hline Type of animals (in vivo) & $\begin{array}{l}\text { Disease model used } \\
\text { (in vivo) }\end{array}$ & Functions & References \\
\hline Rats & MCAO & $\begin{array}{l}\downarrow \text { cerebral infarct volume } \\
\downarrow \text { cerebral injury }\end{array}$ & {$[163]$} \\
\hline p-Hydroxybenzyl alcohol & In vitro/ex vivo & & \\
\hline Cells used (in vitro) & Inducer(s) & Functions & References \\
\hline RAW 264.7 cells & LPS & $\downarrow$ nitric oxide production & {$[164]$} \\
\hline BV-2 cells & LPS & $\downarrow$ nitric oxide production & {$[165]$} \\
\hline PC-12 cells & $\mathrm{H}_{2} \mathrm{O}_{2}$ & $\downarrow$ cell death & {$[166]$} \\
\hline p-Hydroxybenzyl alcohol & In vivo & & \\
\hline Type of animals (in vivo) & $\begin{array}{l}\text { Disease model used } \\
\text { (in vivo) }\end{array}$ & Functions & References \\
\hline Rats & MCAO & $\begin{array}{l}\downarrow \text { brain damage } \\
\uparrow \text { protein disulfide isomerase (PDI) and 1-Cys peroxiredoxin (1-Cys } \\
\text { Prx) transcription levels }\end{array}$ & [167] \\
\hline Rats & MCAO & $\begin{array}{l}\text { Modulate PDI and Nrf2 gene expressions and several neurotrophic } \\
\text { factors }\end{array}$ & {$[166]$} \\
\hline
\end{tabular}

mediators and its potential mechanisms in LPS-activated microglia. The study showed that rhynchophylline reduced the productions of nitric oxide, prostaglandin E2 $\left(\mathrm{PGE}_{2}\right)$, MCP-1, TNF- $\alpha$, and IL- $1 \beta$ [56]. Besides, mRNA levels of inducible nitric oxide synthase (iNOS) and cyclo-oxygenase2 (COX-2) were also suppressed by rhynchophylline [56]. The molecular mechanisms for the inhibitions were due to the blocking of the NF- $\kappa \mathrm{B}$ activation and the suppression of ERK and p38 phosphorylations in activated microglia [56]. Apart from rat primary microglia, rhynchophylline and isorhynchophylline effectively suppressed the release of nitric oxide, TNF- $\alpha$, and IL- $1 \beta$ via suppressions of iNOS protein level, ERK and p38 phosphorylations, and degradation of $\mathrm{I} \kappa \mathrm{B} \alpha$ in LPS-activated murine N9 microglial cell line, with isorhynchophylline showing more potent inhibition [55].

Isorhynchophylline exerted protective effect upon oxidative stress. In a recent study, isorhynchophylline was found to possess neuroprotective effects against $\mathrm{A} \beta$-induced neurotoxicity in PC12 cells [58]. The protections were due to the reduction of intracellular ROS and malondialdehyde (MDA) levels, induction of glutathione (GSH) level, and stabilization of mitochondrial membrane potential [58]. In addition, isorhynchophylline suppressed the mitochondrial pathway of cellular apoptosis by reducing the formation of 

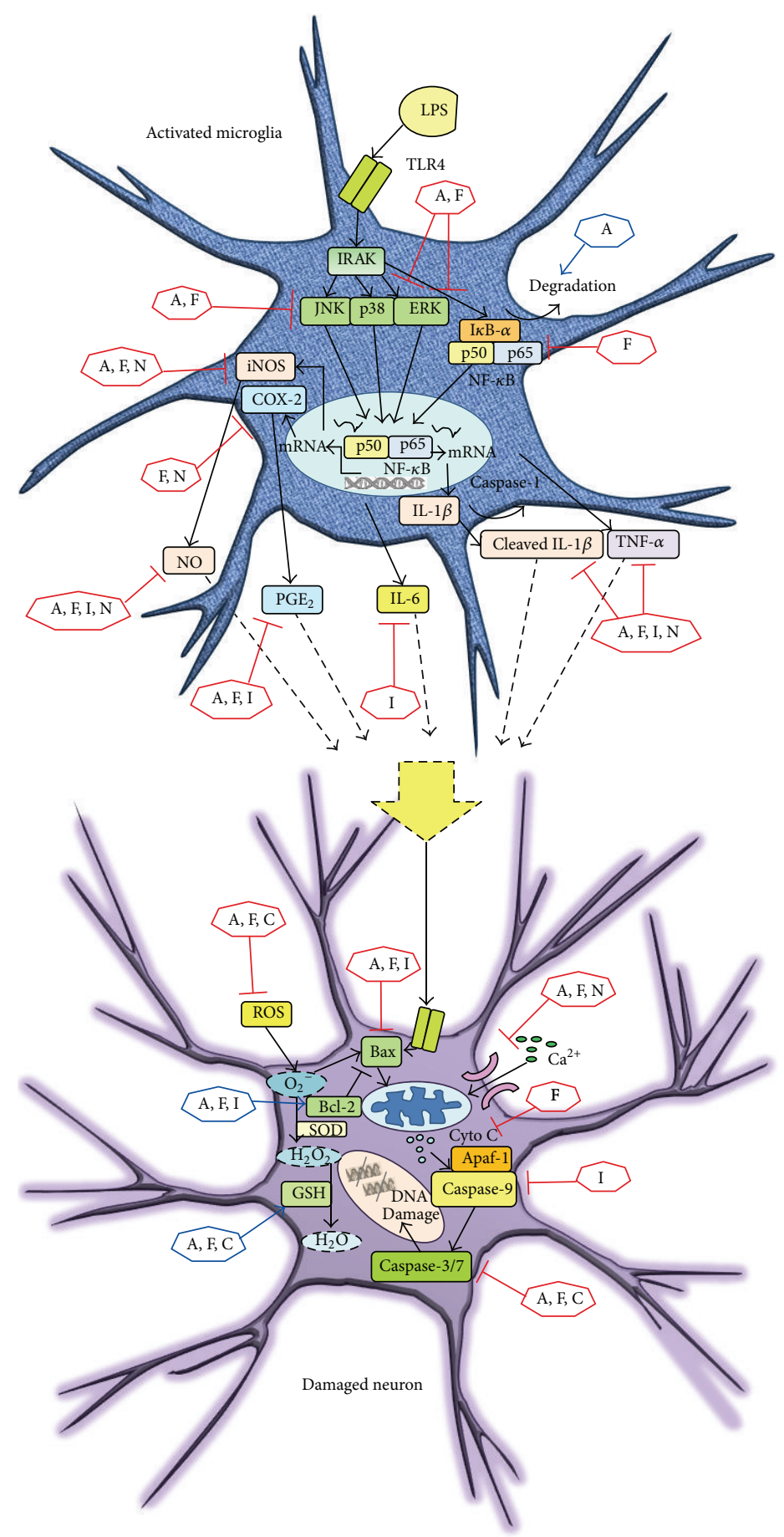
A: alkaloids
F: flavonoids
Protein
I: iridoids
C: carotenoids
$\mathrm{N}$ : natural phenols

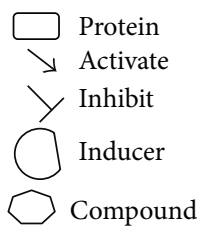
Deceptor
'v Trigger
)( Ion channel
(-) Chemical products
ज्ञा Mitochondrion

FIGURE 6: Summary of the effects of different groups of compounds from GUD on the signaling pathways involved in inflammatory responses in microglia and apoptosis in neuronal cells in neurodegenerative diseases. 
DNA fragmentation and the activity of caspase- 3 as well as moderating the ratio of $\mathrm{Bcl}-2 / \mathrm{Bax}$ expression [58].

Rhynchophylline was found to have neuroprotective effects upon the induction of neurotoxin. Dopamine-induced apoptosis of NT2 neurons has been suppressed by rhynchophylline [61]. In another study using rat primary cortical neurons, rhynchophylline protected against methamphetamine (MA)-induced neurotoxicity [63]. Excessive activation of NMDA subtype glutamate receptors by glutamate triggered neuronal cell damage in the brain [65]. Rhynchophylline and isorhynchophylline were shown to suppress glutamate-induced neuronal death in rat cerebellar granule cells by inhibition of $\mathrm{Ca}^{2+}$ influx [59] and they both acted as noncompetitive antagonists of NMDA receptor expressed in Xenopus oocytes [60]. Further investigation using deprivation of oxygen and glucose-induced neuronal damage in rat hippocampus showed that both rhynchophylline and isorhynchophylline suppressed the in vitro ischemiainduced neuronal damage [62]. The inhibitory effects might attribute to the interactions of rhynchophylline and isorhynchophylline with neurotransmitters receptors other than the NMDA subtype such as muscarinic $\mathrm{M}_{1}$ and $5-\mathrm{HT}_{2}$ receptors [62].

Aberrant expressions and aggregation of $\alpha$-synuclein $(\alpha-$ syn) in neurons are the pathogenic factors of PD [66]. A recent study suggested that isorhynchophylline induced autophagy in different neuronal cell lines including N2a, SHSY5Y, and PC12 cells and also in primary cortical neurons [64]. The induction of autophagy was due to the promotion of clearance of wild-type, A53T and A30P $\alpha$-syn monomers, $\alpha$ syn oligomers, and $\alpha$-syn/synphilin-1 aggresomes in neuronal cells via the autophagy-lysosome pathway [64]. Besides, isorhynchophylline reduced the wild-type and A53T $\alpha$-syn protein expressions in differentiated human dopaminergic neurons [64].

The anti-inflammatory effect of rhynchophylline has been demonstrated in an in vivo model. In a kainic acid-induced seizures rat model, rhynchophylline has the antiepileptic effects associated with the reduction of the superoxide anions levels, JNK phosphorylation, and NF- $\kappa$ B activation [57].

2.2. Leonurine. Leonurine, another alkaloid present in Herba Leonuri, has been demonstrated as an effective cardiovascular agent in preclinical studies. Its neuroprotective effect on neuronal cells has also been documented [67-69]. In an in vitro study, leonurine protected SH-SY5Y cells from cytotoxicity and apoptosis induced by 6-OHDA [67]. The underlying mechanisms were due to its anti-inflammatory and antiapoptotic effects by ameliorating intracellular ROS generation, downregulating of proapoptotic Bax, and upregulating of antiapoptotic $\mathrm{Bcl}-2$ in both $\mathrm{mRNA}$ and protein levels [67]. The therapeutic potential of leonurine on brain injury has been demonstrated using transient rat middle cerebral artery occlusion (MCAO) models. With the pretreatment of leonurine, the infarct volume of the neurological impairment of rats was found to be reduced after MCAO [68]. Moreover, the mitochondrial ROS was reduced as a result of leonurine treatment, indicating that leonurine possessed antioxidant activity to exert its antiapoptotic effect by preserving mitochondrial function [68]. A similar study also demonstrated the antioxidant effect of leonurine, which reduced the infarct volume and improved the neurological deficit of rats after MCAO [69]. At the same time, it also increased the activities of antioxidant enzymes including superoxide dismutase and glutathione peroxidase [69].

\section{Flavonoids}

Flavonoids represent the largest group of plant-specific secondary metabolites for flower coloration. They chemically consist of 15 carbon atoms arranged in C6-C3-C6 skeleton. They possess a wide spectrum of biological activities including anti-inflammatory, anticancer, and antioxidative effects [70]. The antioxidative effect may result from direct scavenging of ROS, high propensity to electron transfer, and chelating ferrous 1 ions by flavonoids [71].

3.1. Quercetin and Catechin. Quercetin and catechin are widely studied for their potential pharmacological properties on neurodegenerative diseases based on their underlying mechanisms related to anti-inflammatory $[72,73]$, antioxidative [74-77], and neuroprotective [76-83] effects on both in vitro and in vivo neural damage models.

Quercetin was reported to have anti-inflammatory effects on LPS-induced N9 microglial cells by suppressing IL- $1 \alpha$ and TNF- $\alpha$ mRNA levels [72]. Moreover, quercetin reduced inflammation-mediated apoptotic neuronal cell death in the microglial-neuronal coculture system [72]. In addition, quercetin inhibited overproduction of nitric oxide and overexpression of iNOS in dopaminergic neurotoxin 6-OHDAinduced PC12 cells [73].

Antioxidative effects of flavonoids associated with neural diseases have been extensively studied. In the rat primary cultures, both quercetin and catechin protected the mesencephalic cultures from oxidative insult by N-methyl-4phenyl-1,2,3,6-tetrahydropyridinium hydrochloride $\left(\mathrm{MPP}^{+}\right)$ [75]. Catechin increased the cellular viability and $\left[{ }^{3} \mathrm{H}\right] \mathrm{DA}$ uptake by reducing the injury produced by hydrogen peroxide $\left(\mathrm{H}_{2} \mathrm{O}_{2}\right)$, 4-hydroxynonenal (4-HNE), rotenone, and 6-OHDA [75]. Most recently, a study using P19 neurons obtained by the differentiation from mouse teratocarcinoma P19 cells was investigated. The study showed that quercetin increased the neuronal viability by diminishing ROS generation and inhibiting nuclear condensation, caspases-3 and 7 activities, and poly(APD-ribose) polymerase upregulation under $\mathrm{H}_{2} \mathrm{O}_{2}$-induced oxidative stress [76].

Flavonoids were found to possess antioxidant activities [84] and exert protective effects on neuronal cells from oxidative stress-induced neurotoxicity $[75,85]$. Catechin was proven to exert protective effects against glutamate-induced neuronal death in cultured rat cerebellar granule cells by inhibiting $\mathrm{Ca}^{2+}$ influx [78]. Besides, more investigations were focused on the neuroprotective effects of quercetin in neuronal cells. One of the studies using rat cortical neuronal cultures showed that quercetin significantly attenuated $\mathrm{A} \beta_{(1-42)}$-induced cytotoxicity, protein oxidation, lipid 
peroxidation, and apoptosis [79]. Apart from the primary cultures, oxidative stress was applied to neuronal cell lines to evaluate the effects of quercetin on the apoptotic cascades. Quercetin was found to suppress the apoptotic neuronal cell death by inhibiting the activation of caspase cascade through moderating the expression of proapoptotic gene (Bax) and antiapoptotic gene (Bcl-2) in $\mathrm{MPP}^{+}$- and $\mathrm{H}_{2} \mathrm{O}_{2}$-induced $\mathrm{PC} 12$ and SH-SY5Y cells, respectively $[80,81]$.

Quercetin and catechin have been investigated to demonstrate their neuroprotective properties in the in vivo model. Catechin was found to attenuate monoamine oxidase B (MAO-B) activity in rat brain which provided protection against oxidative neurodegeneration [74]. In a repeated cerebral ischemia rat model, quercetin improved spatial memory impairment and decreased neuronal cell death in the hippocampal CA1 area [82]. Moreover, liposomal quercetin reduced cerebral damage provoked by permanent $\mathrm{MCAO}$ ( $\mathrm{pMCAO}$ ) by protecting against ischemic lesions and increasing GSH levels in ipsilateral striatum and cortex in rats [83]. Besides, in the 6-OHDA-induced rat model of PD, quercetin defended against oxidative stress and reduced dopaminergic neuronal loss by increasing striatal dopamine and antioxidant enzyme levels together with decreasing protein carbonyl content in striatum [77]. Recently, zebra fish has been used as a PD disease model. Quercetin prevented 6-OHDA-stimulated dopaminergic neuron loss by downregulating the overexpressions of IL- $1 \beta$, TNF- $\alpha$, and COX-2 in zebra fish [73].

Despite the extensive studies of quercetin in various in vitro and in vivo neural disease models, the neuroprotective effect of quercetin remains controversial due to its inability to cross the blood-brain barrier under in vivo conditions $[86,87]$. More mechanistic studies have to be investigated in order to confer the conclusions.

3.2. Rutin. Rutin, comprising quercetin and disaccharide rutinose, is a member of flavonoids also called vitamin $\mathrm{P}$ present in Herba Leonuri. It is regarded as an important nutritional supplement due to the pharmacological properties including anticarcinogenic, cardioprotective, antioxidant, and anti-inflammatory activities [88]. The anti-inflammatory activity of rutin has been well documented in several studies. In vitro, rutin inhibited LPS-induced nitric oxide production and iNOS gene expression in a concentration-dependent manner in RAW 264.7 cells [89]. It was found to dose dependently attenuate $\mathrm{A} \beta_{42}$-induced cytotoxicity in SH-SY5Y neuroblastoma cells by inhibiting the formation of ROS and nitric oxide through the reduction of iNOS activity [90], suggesting that it can be used to treat AD. Furthermore, rutin modulated the production of proinflammatory cytokines including TNF- $\alpha$ and IL- $1 \beta$ in A $\beta_{42}$-induced BV-2 microglia [90].

The neuroprotective effect of rutin was investigated in 6-OHDA-induced PD rat model. Rutin showed antiinflammatory effect by reducing the productions of TNF$\alpha$, IL- $1 \beta$, and nitric oxide as well as the expression of iNOS in 6-OHDA treated rats [91]. Moreover, rutin suppressed trimethyltin (TMT)-induced microglial activation by reducing the mRNA levels of IL-1 $\beta$ and IL-6, which resulted in the reduction of inflammation or neuron loss in the hippocampus of rats [92]. Another study also demonstrated that rutin reduced cerebral ischemia-induced neuronal death in the hippocampal region CA1 of rats [93]. The results illustrate that rutin is a potent anti-inflammatory agent for treating neurodegenerative diseases.

3.3. Baicalein. Baicalein, a flavonoid originally isolated from the root of Scutellaria baicalensis Georgi, has various biological activities including anti-inflammatory [94], antioxidant, antiviral [95], and antifibrotic effects [96]. In vitro, baicalein possessed anti-inflammatory effect by inhibiting hypoxiainducible factor- 1 alpha (HIF- $1 \alpha$ ) protein accumulation and HIF-1 transcriptional activation on hypoxia-induced BV2 microglia [97]. Moreover, it suppressed the expressions of iNOS, COX-2, and VEGF by inhibiting ROS and PI3kinase/Akt pathway on hypoxia-induced BV2 microglia [97]. Using LPS as an inducer, baicalein was found to almost completely block the activation of microglia by attenuating the excessive productions of TNF- $\alpha$ and free radicals including nitric oxide and superoxide [94]. Baicalein was also found to inhibit LPS/IFN- $\gamma$-induced nitric oxide production and activation of iNOS gene expression in primary microglia and BV-2 cells, through the inactivation of NF-IL6 [98].

In terms of antioxidative effect, baicalein protected the neuronal SH-SY5Y cells from 6-OHDA-induced cell apoptosis through the suppressions of caspase-3, caspase-9, and phospho-JNK activation as well as ROS generation $[99,100]$. Baicalein protected HT22 mouse hippocampal neuronal cells against thapsigargin (TG) and brefeldin A (BFA)-induced apoptosis through the inhibition of ROS accumulation [101]. Moreover, a study demonstrated that baicalein inhibited ROS-mediated cytotoxic effects through the modulation of ERKs activation and the induction of heme oxygenase-1 (HO-1) protein expression on $\mathrm{H}_{2} \mathrm{O}_{2}$-induced rat glioma C6 cells [102]. Another study found that baicalein suppressed neurotoxin rotenone-induced apoptosis and inhibited the accumulation of ROS on rotenone-induced toxicity in PC12 cells [103].

In vivo, baicalein has been demonstrated to improve functional recovery and reduce contusion volumes of rats after controlled cortical impact injury [104]. Moreover, it also significantly reduced the mRNA and protein levels of proinflammatory cytokines including TNF- $\alpha$, IL- $1 \beta$, and IL- 6 [104]. In general, the in vitro and in vivo data were suggestive of the potential role of baicalein in protecting the brain cells from apoptosis.

3.4. Baicalin. Baicalin, a flavonoid compound isolated from Scutellaria baicalensis Georgi, has been widely used in China to treat the inflammatory diseases and ischemic stroke for thousands of years. In vitro, RAW 264.7 cells induced by LPS have been used as a model to study the anti-inflammatory effect of baicalin. One of the studies demonstrated that baicalin inhibited nitric oxide production and iNOS gene expression [105]. Another study found that baicalin inhibited the productions of proinflammatory mediators including TNF- $\alpha$, ET-1, and thromboxane A2 (TXA2) [106]. Moreover, baicalin possessed antioxidative effect by reducing ROS 
production, inhibiting 5-LOX translocation to the nuclear envelope, and inhibiting p38 phosphorylation in oxygenglucose deprivation $/ \mathrm{H}_{2} \mathrm{O}_{2}$-induced PC12 cells [107].

In vivo, baicalin was found to reduce neurological deficit scores and cerebral infarct volume of Sprague-Dawley rats after pMCAO [108]. The underlying mechanisms were due to the anti-inflammatory effect of baicalin that significantly reduced the expressions of iNOS and COX-2 mRNA levels in rat brain [108]. Moreover, it also possessed antioxidative effect to inhibit neuronal apoptosis and the expression of cleaved caspase- 3 protein [108]. Tu et al. found that baicalin reduced the expression of TLR $2 / 4$ and NF- $\kappa \mathrm{B}$ and attenuated the serum content of proinflammatory cytokines including TNF- $\alpha$ and IL- $1 \beta$ [109]. Another study demonstrated that rats treated with baicalin show significant reduced neurological deficit scores and infarction volume [110]. Further investigations revealed that the neuroprotective effects of baicalin were due to the inhibition of NF- $\kappa$ B p 65 [110]. Similar study demonstrated that baicalin inhibited the transcription of NF$\kappa \mathrm{B}$ and the generation of inflammatory mediator TNF- $\alpha$ in the injured spinal cord tissue of rats [111]. Moreover, baicalin reduced the expression of Bax and increased the expression of Bcl-2 [111].

3.5. Wogonin. Wogonin is one of the flavonoids from the root of Scutellaria baicalensis Georgi. The anti-inflammatory effect of wogonin has been recognized for a long time. A previous study demonstrated that the mechanisms of antiinflammatory effect of wogonin involved the modulation of mediators and enzyme systems including cytokines, COX2 , and iNOS [112-116]. For instance, wogonin inhibited LPS-induced COX-2 expression and $\mathrm{PGE}_{2}$ production in RAW 264.7 cells [112]. In addition, wogonin decreased the productions of proinflammatory cytokines including TNF$\alpha$ and IL- 6 in LPS-induced microglia [116]. Furthermore, wogonin completely suppressed the activity of $\mathrm{NF}-\kappa \mathrm{B}$ in MCP-1-stimulated microglia [117]. Wogonin was found to inhibit nitric oxide production through the suppression of iNOS on LPS-induced RAW 264.7 cells [118].

The neuroprotective effect of wogonin was demonstrated using animal models. Wogonin was found to reduce the total infarction volume and improve the behavioral deficits in rats after pMCAO [119]. Another study also demonstrated that wogonin exerted inhibitory activity on LPS-induced nitric oxide production through the suppression of iNOS expression in Balb/c mice [113].

3.6. Oroxylin A. Oroxylin A, being one of the principle components in Scutellaria baicalensis Georgi, possesses strong anti-inflammatory effect by inhibiting LPS/Bcl-induced iNOS and COX-2 gene expressions in RAW 264.7 cells [120]. The mechanism was due to the inhibition of the binding of transcription factor NF- $\kappa \mathrm{B}$ to the iNOS promoter [120]. Furthermore, oroxylin A inhibited 12-lipoxygenase in human platelets [121].

In vivo, pretreatment of oroxylin $\mathrm{A}$ ameliorated the memory impairment of $\mathrm{A} \beta_{(25-35)}$-induced mice, through the reduction of astrocyte and microglia activations and iNOS expression [122]. The result revealed that oroxylin A can be potentially used for treating PD.

3.7. Apigenin. The anti-inflammatory activity of apigenin, presents in Herba Leonuri, has been well studied. Apigenin inhibited the protein and mRNA expressions of COX-2 and iNOS in LPS-induced RAW 264.7 cells through the inhibition of $\mathrm{I} \kappa \mathrm{B}$ kinase activity [123]. Apigenin also inhibited the productions of proinflammatory cytokines including TNF- $\alpha$, IL-6, and IL-1 $\beta$ on LPS-stimulated human peripheral blood mononuclear cells [124]. It also reduced the mRNA levels of TNF- $\alpha$ and IL-1 $\beta$ in LPS-induced J774.2 macrophages [125]. Apigenin inhibited the production of nitric oxide and $\mathrm{PGE}_{2}$ by suppressing the expression of iNOS and COX2 protein, respectively. Moreover, apigenin suppressed the phosphorylations of p38 and JNK but not the activity of ERK [126].

In vivo, apigenin significantly reduced the infarct volume of mice in MCAO model. Also, it inhibited microglial activation, resulting in the reduction of damage in various neurodegenerative diseases [126].

3.8. Kaempferol. Kaempferol can be found from Herba Leonuri, possessing anti-inflammatory activity as illustrated using LPS-induced J774.2 macrophages as the model. The compound was found to decrease the number of TNF- $\alpha$ mRNA copies and inhibit IL- $1 \beta$ gene expression in LPSactivated J774.2 macrophages [125]. Besides, it also effectively inhibited the productions of $\mathrm{PGE}_{2}$ and nitric oxide as well as downregulated microsomal $\mathrm{PGE}_{2}$ synthase-1 (mPGES-1) and iNOS expressions $[127,128]$. The mechanisms were due to the inhibition of the activation of NF- $\kappa \mathrm{B}$ and signal transducer and activator of transcription 1 (STAT-1) [128]. In combination with another flavonoid chrysin, kaempferol was found to significantly synergize their inhibitory effect on nitric oxide, $\mathrm{PGE}_{2}$, and TNF- $\alpha$ secretions in LPS-induced RAW 264.7 macrophages [129]. The in vivo experiment demonstrated that kaempferol protected the rat brain from damage in the temporal-frontal areas of neocortex and striatum [130]. Kaempferol also protected the rat brain against nitrosativeoxidative stress after ischemia/reperfusion, as shown by nearly complete protection against the increase of protein nitrotyrosines, and also afford strong protection against the increase of apoptotic cell death and biochemical markers of apoptosis including caspase- 9 activity and poly(ADP-ribose) polymerase degradation [130].

3.9. Hyperoside. Hyperoside (Hyp, quercetin-3-O-galactoside), a flavonoid compound, is usually found in Herba Leonuri. Hyperoside was shown to exert an anti-inflammatory action through suppressing the productions of TNF- $\alpha$, IL-6, and nitric oxide in LPS-induced mouse peritoneal macrophages [131]. The antioxidative effect of hyperoside was demonstrated by investigating its effects on $\mathrm{H}_{2} \mathrm{O}_{2}$ and tertbutyl hydroperoxide-induced PC12 cytotoxicity. The result showed that hyperoside efficiently prevented PC12 cells from shrinking and turning against apoptosis as indicated by the decrease of extracellular lactate dehydrogenase levels 
[132]. The antiapoptotic effect of hyperoside was found to be partially dependent on suppressing the ROS production, inhibiting the caspase-3 activity [133]. It was also associated with increasing the expression of the antiapoptotic protein $\mathrm{Bcl}-2$ and decreasing the expression of proapoptotic protein Bax in sodium azide-mediated PC12 cells [133]. In vivo, hyperoside reduced the infarct sizes and water content, and neurology score of the rat brain underwent focal cerebral ischemia reperfusion injury [134].

\section{Iridoids}

Iridoids, the secondary metabolites found in a wide variety of plants, are monoterpenes biosynthesized from isoprene. Chemically, they consist of a cyclopentane ring fused to a six-membered oxygen heterocycle. The iridoids produced by plants are primarily used to protect against herbivores or to prevent the plants against infection. This group of compound has attracted much interest for medicinal use because of their pharmaceutical activities including cardiovascular, anti-inflammatory, neuroprotective, antitumor, antiviral, and immunomodulatory activities [135].

4.1. Genipin and Geniposide. Iridoid compounds found in Gardenia jasminoides such as genipin and geniposide have been demonstrated to have diverse pharmacological activities including anti-inflammatory [136-138], antioxidative [139142], neuroprotective [143-148], and neurotrophic [149-152] effects. Thus, the iridoid compounds have been considered to be the treatment of various neurological disorders.

Genipin, the aglycone of geniposide, has been examined to evaluate its anti-inflammatory properties in the in vitro experiments. Genipin dose dependently inhibited the productions of $\mathrm{NO}$ and $\mathrm{PGE}_{2}$ as well as the expressions of iNOS, COX-2, IL-6, IL-1 $\beta$, and TNF- $\alpha$ via downregulation of NF- $\kappa$ B activation in LPS-stimulated RAW 264.7 macrophage [136]. Besides, microglial activations were reduced by genipin through the inhibitions of nitric oxide, TNF- $\alpha$, IL- $1 \beta, \mathrm{PGE}_{2}$, intracellular ROS productions, and NF- $\kappa$ B activation in LPSstimulated rat brain microglial cells [137]. Other than LPS, more pathophysiological stimuli $\mathrm{A} \beta$ in combination with IFN- $\gamma$ were used to stimulate the microglial cells. Both pretreatment and posttreatment of genipin reduced nitric oxide release in $\mathrm{A} \beta$ and IFN $-\gamma$ stimulated microglia [137].

Recently, genipin has been isolated from Eucommia ulmoides Oliver in our laboratory. The biological effect of genipin was studied and the results showed that genipin dose dependently inhibited the productions of nitric oxide and TNF- $\alpha$ as well as iNOS mRNA levels in LPS-stimulated BV-2 mouse microglial cells (data not shown). The inhibition was due to the suppressive effect of genipin on PI3K/Akt activation. Moreover, genipin protected Neuro-2a cells against neurotoxicity stimulated by the conditioned media transferred from LPS-challenged BV-2 cells.

Oxidative stress in brain is associated with the potential causative factor of age-related neurodegenerative disorders [153]. Compounds with capability to induce endogenous antioxidative proteins were considered as a therapeutic strategy for attenuating the oxidative damage and cell death in the brain. Geniposide was able to protect against 3-morpholinosydnonimine hydrochloride (SIN-1)-induced oxidative stress by enhancing HO-1 expression in both PC12 cells and primary hippocampal neurons [139, 142]. Geniposide also exerted protective effect against $\mathrm{H}_{2} \mathrm{O}_{2}$ by inducing $\mathrm{Bcl}-2$ expression via MAPK and PI3K signaling pathways in PC12 cells [140, 141].

As the consequence of oxidative stress, induction of mitochondrial-mediated apoptosis is correlated with the development of neurodegenerative diseases. A number of studies focused on the regulation of mitochondrial pathways including the apoptosis-related protein expressions and the neurotoxin-induced neuronal cell death. Cobalt chloride $\left(\mathrm{CoCl}_{2}\right)$-induced cell death in PC12 cells, which mimic hypoxia-induced neuronal cytotoxicity, was protected by geniposide through decreasing the expression of Bax, P53, and caspase-9 while increasing the expression of Bcl-2 [147]. Besides, in the model of rat hippocampal slice culture, geniposide protected neuronal cell death from oxygen and glucose deprivation [148]. In addition, genipin protected neuronal cells against cytotoxicity induced by various neurotoxic agents including $\mathrm{A} \beta_{(25-35)}$ [145], 6-OHDA [144], A23187 (a calcium ionophore) [143], and tunicamycin [146].

Anti-inflammatory effects of genipin have been evaluated in the in vivo models. Neuroinflammation induced by systemic administration of LPS in mouse has been inhibited by genipin through the reduction of TNF- $\alpha$ and IL- 6 productions in plasma [136]. Genipin could also provide neuroprotection by reducing the productions of various neurotoxic molecules from activated microglia [137]. Moreover, genipin effectively inhibited carrageenan-induced paw edema [136, 138], air pouch formation, and nitric oxide content in the exudates of mouse models [138].

\section{Carotenoids}

Carotenoids are tetraterpenoids naturally occurring in plants and other photosynthetic organisms. The structure of carotenoids is composed of a central carbon chain of alternating single and double bonds. The conjugated double bonds are well known to be responsible for the pigments of the carotenoids. They possessed antioxidant [154], cardiovascular [155], and anticancer [155] effects as well as reduced the risk of neurodegenerative diseases [156].

5.1. Crocetin. Crocetin is a natural carotenoid compound found in Gardenia jasminoides. Antioxidant effects of crocetin have been evaluated in both in vitro and in vivo models. In one model using stroke-prone spontaneously hypertensive rat (SHRSP), crocetin reduced oxidative stress in the isolated brain by acting as a scavenger of ROS [157]. In another study using SH-SY5Y cells, crocetin protected against cellular apoptosis by repressing ROS production and decreasing caspase-3 activation [158]. Neuromodulatory effect of crocetin has been investigated in the in vivo experiment. Report showed that pretreatment of crocetin enhanced the antioxidant enzyme activity, GSH, and dopamine levels whereas attenuated thiobarbituric acid reactive substance (TBARS) level in 6-OHDAinduced rats [159]. 


\section{Phenolic Compounds}

Phenolic compounds are believed to be one of the most widely occurring groups of phytochemicals throughout the plant kingdom. These compounds contain at least one aromatic ring with one or more hydroxyl groups attached. They contain hydrogen or electron-donating groups to interact with the radicals, resulting in antioxidant activities.

6.1. Gastrodin. Gastrodin is the main component isolated from the rhizome of Gastrodia elata. This compound possessed strong anti-inflammatory and antioxidant effects [160163]. In vitro, pretreatment of gastrodin has been demonstrated to reduce the neurotoxicity on hypoxia-induced rat cortical neurons [160]. It also protected against oxygen/glucose deprivation and glutamate-induced neuronal cell death in cultured rat hippocampal neurons by inhibiting $\mathrm{Ca}^{2+}$ and nitric oxide productions [161]. Gastrodin significantly reduced the protein and mRNA expression levels of iNOS, COX-2, TNF- $\alpha$, and IL- $1 \beta$ in LPS-induced BV-2 cells [162]. Furthermore, levels of phosphorylated ERK1/2, JNK, and p38 MAPKs were significantly reduced by the pretreatment of gastrodin in LPS-stimulated microglial cells [162].

In vivo, gastrodin decreased the volume of cerebral infarction and ameliorated the cerebral injury in the rats of cerebral ischemia reperfusion $[161,163]$. The studies revealed that gastrodin had a neuroprotective effect against neurodegenerative diseases.

6.2. p-Hydroxybenzyl Alcohol. p-Hydroxybenzyl alcohol is one of the major components in Gastrodia elata Blume (GE). It incorporated with copolyoxalate to exert excellent antioxidant activity by inhibiting nitric oxide production through the suppression of iNOS expression in LPS-activated RAW 264.7 cells [164]. Without copolyoxalate, p-Hydroxybenzyl alcohol inhibited nitric oxide production through the suppression of iNOS expression in LPS-activated BV-2 cells [165]. Moreover, p-Hydroxybenzyl alcohol also prevented PC12 cell death induced by $\mathrm{H}_{2} \mathrm{O}_{2}$ [166].

In vivo, p-Hydroxybenzyl alcohol provided neuroprotection by preventing brain damage through the increased expression of genes encoding antioxidant proteins including protein disulfide isomerase (PDI) and 1-Cys peroxiredoxin (1Cys Prx) after transient focal cerebral ischemia in the rat brain [167]. Moreover, pretreatment of p-Hydroxybenzyl alcohol promoted functional recovery as indicated by the neurological severity score [166]. It also increased the expressions of PDI, nuclear factor-E2-related factor 2 (Nrf2), and several neurotrophic factor genes including glial cell line-derived neurotrophic factor (GDNF), brain-derived neurotrophic factor (BDNF), nerve growth factor (NGF), and myelin basic protein (MBP) genes [166]. The results indicate that $\mathrm{p}$ Hydroxybenzyl alcohol can protect against neuroinflammation and brain damage.

\section{Conclusions}

The unsatisfactory outcome of existing drugs leads to the exploration of alternative medicines for treating acute and chronic neurodegenerative diseases. Traditional Chinese medicines used as alternative medicines are gaining more attention in western countries for curing various kinds of diseases. They are believed to be empirically effective and safe for thousands of years. With the help of modern experimentbased research, the compounds that are responsible for the biological effects of the herbs are isolated and their molecular modes of action are also characterized. In this review, we summarize the pharmacological effects of five groups of compounds including alkaloids, flavonoids, iridoids, carotenoids, and natural phenols from GUD. These compounds exert strong anti-inflammatory effect by inhibiting the production of cytokines, chemokines, and proteases in neuronal cells. In addition to the anti-inflammatory effect, they also exert strong antioxidative and antiapoptotic effects by reducing the generation of ROS, resulting in the reduction of necrosis and apoptosis of the neuronal cells.

\section{Acknowledgments}

This project was supported in part by grants from Professor Francis SK Lau Research Funds and PuraPharm International awarded to Professor A. Lau.

\section{References}

[1] R. Scatena, G. E. Martorana, P. Bottoni, G. Botta, P. Pastore, and B. Giardina, "An update on pharmacological approaches to neurodegenerative disease," Expert Opinion on Investigational Drugs, vol. 16, no. 1, pp. 59-72, 2007.

[2] D. A. Linseman, "Targeting oxidative stress for neuroprotection," Antioxidants and Redox Signaling, vol. 11, no. 3, pp. 421423, 2009.

[3] S.-M. Lucas, N. J. Rothwell, and R. M. Gibson, "The role of inflammation in CNS injury and disease," British Journal of Pharmacology, vol. 147, no. 1, pp. S232-S240, 2006.

[4] G. W. Kreutzberg, "Microglia: a sensor for pathological events in the CNS," Trends in Neurosciences, vol. 19, no. 8, pp. 312-318, 1996.

[5] U.-K. Hanisch, "Microglia as a source and target of cytokines," Glia, vol. 40, no. 2, pp. 140-155, 2002.

[6] H. Nakanishi, "Microglial functions and proteases," Molecular Neurobiology, vol. 27, no. 2, pp. 163-176, 2003.

[7] C. A. Colton and D. L. Gilbert, "Microglia, an in vivo source of reactive oxygen species in the brain," Advances in neurology, vol. 59, pp. 321-326, 1993.

[8] A. Ghoshal, S. Das, S. Ghosh et al., "Proinflammatory mediators released by activated microglia induces neuronal death in Japanese encephalitis," Glia, vol. 55, no. 5, pp. 483-496, 2007.

[9] C. Zhu, Z. Xiong, X. Chen et al., "Artemisinin attenuates lipopolysaccharide-stimulated proinflammatory responses by inhibiting NF- $\kappa$ B pathway in microglia cells," PLoS ONE, vol. 7, no. 4, Article ID e35125, 2012.

[10] M. Ii, M. Sunamoto, K. Ohnishi, and Y. Ichimori, " $ß$-amyloid protein-dependent nitric oxide production from microglial cells and neurotoxicity," Brain Research, vol. 720, no. 1-2, pp. $93-$ 100, 1996.

[11] C. K. Combs, J. Colleen Karlo, S.-C. Kao, and G. E. Landreth, " $\beta$-amyloid stimulation of microglia anti monocytes results in TNF $\alpha$-dependent expression of inducible nitric oxide synthase 
and neuronal apoptosis," Journal of Neuroscience, vol. 21, no. 4, pp. 1179-1188, 2001.

[12] S. S. Shaftel, W. S. T. Griffin, and K. M. Kerry, "The role of interleukin-1 in neuroinflammation and Alzheimer disease: an evolving perspective," Journal of Neuroinflammation, vol. 5, article 7, 2008.

[13] J. R. Lokensgard, S. Hu, W. Sheng et al., "Robust expression of TNF- $\alpha$, IL-1 $\beta$, RANTES, and IP-10 by human microglial cells during nonproductive infection with herpes simplex virus," Journal of NeuroVirology, vol. 7, no. 3, pp. 208-219, 2001.

[14] R. E. Mrak and W. S. T. Griffin, "Glia and their cytokines in progression of neurodegeneration," Neurobiology of Aging, vol. 26, no. 3, pp. 349-354, 2005.

[15] D. Tweedie, K. Sambamurti, and N. H. Greig, "TNF- $\alpha$ inhibition as a treatment strategy for neurodegenerative disorders: new drug candidates and targets," Current Alzheimer Research, vol. 4, no. 4, pp. 378-385, 2007.

[16] S. L. Montgomery and W. J. Bowers, "Tumor Necrosis Factoralpha and the Roles it Plays in Homeostatic and Degenerative Processes Within the Central Nervous System," Journal of Neuroimmune Pharmacology, vol. 7, pp. 42-59, 2012.

[17] V. Fontaine, S. Mohand-Said, N. Hanoteau, C. Fuchs, K. Pfizenmaier, and U. Eisel, "Neurodegenerative and neuroprotective effects of tumor Necrosis factor (TNF) in retinal ischemia: opposite roles of TNF receptor 1 and TNF receptor 2," The Journal of Neuroscience, vol. 22, no. 7, p. RC216, 2002.

[18] A. D. Bachstetter, B. Xing, L. de Almeida, E. R. Dimayuga, D. M. Watterson, and L. J. Van Eldik, "Microglial p38 $\alpha$ MAPK is a key regulator of proinflammatory cytokine up-regulation induced by toll-like receptor (TLR) ligands or beta-amyloid (A $\beta)$," Journal of Neuroinflammation, vol. 8, article 79, 2011.

[19] H. Pyo, I. Jou, S. Jung, S. Hong, and E.-H. Joe, "Mitogen-activated protein kinases activated by lipopolysaccharide and $\beta$ amyloid in cultured rat microglia," NeuroReport, vol. 9, no. 5, pp. 871-874, 1998.

[20] N. A. Simonian and J. T. Coyle, "Oxidative stress in neurodegenerative diseases," Annual Review of Pharmacology and Toxicology, vol. 36, pp. 83-106, 1996.

[21] W. S. Choi, S. Y. Yoon, and Y. J. Oh, "Differential cell death mechanisms in a dopaminergic neuronal cell line: role of ROS, JNK, caspase and cell death regulating genes in a 6-OHDA or MPP+-induced cell death," Journal of Neurochemistry, vol. 70, pp. S60-S60, 1998.

[22] A. M. S. Mayer, "Therapeutic implications of microglia activation by lipopolysaccharide and reactive oxygen species generation in septic shock and central nervous system pathologies: a review," Medicina, vol. 58, no. 4, pp. 377-385, 1998.

[23] L. Qin, Y. Liu, C. Cooper, B. Liu, B. Wilson, and J.-S. Hong, "Microglia enhance $\beta$-amyloid peptide-induced toxicity in cortical and mesencephalic neurons by producing reactive oxygen species," Journal of Neurochemistry, vol. 83, no. 4, pp. 973-983, 2002.

[24] J. Rodriguez-Pallares, J. A. Parga, A. Muñoz, P. Rey, M. J. Guerra, and J. L. Labandeira-Garcia, "Mechanism of 6-hydroxydopamine neurotoxicity: the role of NADPH oxidase and microglial activation in 6-hydroxydopamine-induced degeneration of dopaminergic neurons," Journal of Neurochemistry, vol. 103, no. 1, pp. 145-156, 2007.

[25] S. B. Shaikh and L. F. B. Nicholson, "Effects of chronic low dose rotenone treatment on human microglial cells," Molecular Neurodegeneration, vol. 4, no. 1, article 55, 2009.
[26] J. S. Beckman and J. P. Crow, "Pathological implications of nitric oxide, superoxide and peroxynitrite formation," Biochemical Society Transactions, vol. 21, no. 2, pp. 330-334, 1993.

[27] X. Zhang, J. Chen, S. H. Graham et al., "Intranuclear localization of apoptosis-inducing factor (AIF) and large scale DNA fragmentation after traumatic brain injury in rats and in neuronal cultures exposed to peroxynitrite," Journal of Neurochemistry, vol. 82, no. 1, pp. 181-191, 2002.

[28] T. H. Liu, J. S. Beckman, B. A. Freeman, E. L. Hogan, and C. Y. Hsu, "Polyethylene glycol-conjugated superoxide dismutase and catalase reduce ischemic brain injury," American Journal of Physiology, vol. 256, no. 2, p. 25/2, 1989.

[29] L. J. Martin, "Mitochondrial and cell death mechanisms in neurodegenerative diseases," Pharmaceuticals, vol. 3, pp. 839-915, 2010.

[30] M. P. Mattson, C. Culmsee, and F. Y. Zai, "Apoptotic and antiapoptotic mechanisms in stroke," Cell and Tissue Research, vol. 301, no. 1, pp. 173-187, 2000.

[31] C.-Y. Liu, C.-F. Lee, and Y.-H. Wei, "Role of reactive oxygen species-elicited apoptosis in the pathophysiology of mitochondrial and neurodegenerative diseases associated with mitochondrial DNA mutations," Journal of the Formosan Medical Association, vol. 108, no. 8, pp. 599-611, 2009.

[32] M. O. Hengartner, "The biochemistry of apoptosis," Nature, vol. 407, no. 6805, pp. 770-776, 2000.

[33] P. Decker, D. Isenberg, and S. Muller, "Inhibition of caspase3-mediated poly(ADP-ribose) polymerase (PARP) apoptotic cleavage by human PARP autoantibodies and effect on cells undergoing apoptosis," Journal of Biological Chemistry, vol. 275, no. 12, pp. 9043-9046, 2000.

[34] D. T. Chao and S. J. Korsmeyer, "BCL-2 family: regulators of cell death, Annual Review of Immunology, vol. 16, pp. 395-419, 1998.

[35] D. J. Kane, T. A. Sarafian, R. Anton et al., "Bcl-2 inhibition of neural death: decreased generation of reactive oxygen species," Science, vol. 262, no. 5137, pp. 1274-1277, 1993.

[36] D. S. Knopman, "Current treatment of mild cognitive impairment and Alzheimer's disease," Current Neurology and Neuroscience Reports, vol. 6, no. 5, pp. 365-371, 2006.

[37] K. Yamada and T. Nabeshima, "Animal models of Alzheimer's disease and evaluation of anti-dementia drugs," Pharmacology and Therapeutics, vol. 88, no. 2, pp. 93-113, 2000.

[38] T. H. Johnston and J. M. Brotchie, "Drugs in development for Parkinson's disease: an update," Current Opinion in Investigational Drugs, vol. 7, no. 1, pp. 25-32, 2006.

[39] A. H. V. Schapira, E. Bezard, J. Brotchie et al., "Novel pharmacological targets for the treatment of Parkinson's disease," Nature Reviews Drug Discovery, vol. 5, no. 10, pp. 845-854, 2006.

[40] W. G. Meissner, M. Frasier, T. Gasser et al., "Priorities in Parkinson's disease research," Nature Reviews Drug Discovery, vol. 10, no. 5, pp. 377-393, 2011.

[41] S. Davis, K. Lees, and G. Donnan, "Treating the acute stroke patient as an emergency: current practices and future opportunities," International Journal of Clinical Practice, vol. 60, no. 4, pp. 399-407, 2006.

[42] N. J. Sucher, "Insights from molecular investigations of traditional Chinese herbal stroke medicines: implications for neuroprotective epilepsy therapy," Epilepsy and Behavior, vol. 8, no. 2, pp. 350-362, 2006.

[43] J.-X. Song, S. C.-W. Sze, T.-B. Ng et al., "Anti-Parkinsonian drug discovery from herbal medicines: what have we got from neurotoxic models?" Journal of Ethnopharmacology, vol. 139, no. 3, pp. 698-711, 2012. 
[44] H. Fruehauf, "Prevention and treatment by chinese herbal medicine, stroke and post-stroke syndrome," The Journal of Chinese Medicine, vol. 44, pp. 22-35, 1994.

[45] T.-X. Zhang, Y.-F. Wang, and J. Ciriello, "The herbal medicine tian ma gou teng yen alters the development of high blood pressure in the spontaneously hypertensive rat," American Journal of Chinese Medicine, vol. 17, no. 3-4, pp. 211-219, 1989.

[46] S. Wang, Y. Chen, D. He et al., "Inhibition of vascular smooth muscle cell proliferation by serum from rats treated orally with Gastrodia and Uncaria decoction, a traditional Chinese formulation," Journal of Ethnopharmacology, vol. 114, no. 3, pp. 458-462, 2007.

[47] C. Napoli and W. Palinski, "Neurodegenerative diseases: insights into pathogenic mechanisms from atherosclerosis," Neurobiology of Aging, vol. 26, no. 3, pp. 293-302, 2005.

[48] D. A. Patten, M. Germain, M. A. Kelly, and R. S. Slack, "Reactive oxygen species: stuck in the middle of neurodegeneration," Journal of Alzheimer's Disease, vol. 20, no. 2, pp. S357-S367, 2010.

[49] A. Brossi, Ed., The Alkaloids-Chemistry and Pharmacology, Academic press, Orlando, Fla, USA, 1986.

[50] A. L. Souto, J. F. Tavares, M. S. Da Silva, M. F. F. M. De Diniz, P. F. De Athayde-Filho, and J. M. Barbosa Filho, "Anti-inflammatory activity of alkaloids: an update from 2000 to 2010," Molecules, vol. 16, no. 10, pp. 8515-8534, 2011.

[51] R. Andraws, P. Chawla, and D. L. Brown, "Cardiovascular effects of Ephedra alkaloids: a comprehensive review," Progress in Cardiovascular Diseases, vol. 47, no. 4, pp. 217-225, 2005.

[52] E. Yamanaka, Y. Kimizuka, and N. Aimi, "Studies of plants containing indole alkaloids. IX. Quantitative analysis on the tertiary alkaloids in various parts of Uncaria rhynchophylla M(IQ)," Yakugaku Zasshi, vol. 103, no. 10, pp. 1028-1033, 1983.

[53] J. Zhang, C. J. Yang, and D. G. Wu, "Studies on the chemical constituents of sharpleaf gambir plant (Uncaria rhynchophylla) (II)," Chinese Traditional and Herbal Drugs, vol. 29, pp. 649-651, 1998.

[54] D. Yuan, B. Ma, C. Wu et al., "Alkaloids from the leaves of Uncaria rhynchophylla And Their Inhibitory Activity on NO production in lipopolysaccharide-activated microglia," Journal of Natural Products, vol. 71, no. 7, pp. 1271-1274, 2008.

[55] D. Yuan, B. Ma, J.-Y. Yang et al., "Anti-inflammatory effects of rhynchophylline and isorhynchophylline in mouse N9 microglial cells and the molecular mechanism," International Immunopharmacology, vol. 9, no. 13-14, pp. 1549-1554, 2009.

[56] Y. Song, R. Qu, S. Zhu, R. Zhang, and S. Ma, "Rhynchophylline attenuates LPS-induced pro-inflammatory responses through down-regulation of MAPK/NF- $\kappa \mathrm{B}$ signaling pathways in primary microglia," Phytotherapy Research, vol. 26, no. 10, pp. 1528-1533, 2012.

[57] C.-L. Hsieh, T.-Y. Ho, S.-Y. Su, W.-Y. Lo, C.-H. Liu, and N.-Y. Tang, "Uncaria rhynchophylla and rhynchophylline inhibit cJun N-terminal kinase phosphorylation and nuclear factor- $\kappa \mathrm{B}$ activity in kainic acid-treated rats," American Journal of Chinese Medicine, vol. 37, no. 2, pp. 351-360, 2009.

[58] Y.-F. Xian, Z.-X. Lin, Q.-Q. Mao, S.-P. Ip, Z.-R. Su, and X.-P. Lai, "Protective effect of isorhynchophylline against $\beta$-amyloidinduced neurotoxicity in PC12 cells," Cellular and Molecular Neurobiology, vol. 32, no. 3, pp. 353-360, 2012.

[59] Y. Shimada, H. Goto, T. Itoh et al., "Evaluation of the protective effects of alkaloids isolated from the hooks and stems of Uncaria sinensis on glutamate-induced neuronal death in cultured cerebellar granule cells from rats," Journal of Pharmacy and Pharmacology, vol. 51, no. 6, pp. 715-722, 1999.
[60] T.-H. Kang, Y. Murakami, K. Matsumoto et al., "Rhynchophylline and isorhynchophylline inhibit NMDA receptors expressed in Xenopus oocytes," European Journal of Pharmacology, vol. 455, no. 1, pp. 27-34, 2002.

[61] J.-S. Shi and H. G. Kenneth, "Effect of rhynchophylline on apoptosis induced by dopamine in NT2 cells," Acta Pharmacologica Sinica, vol. 23, no. 5, pp. 445-449, 2002.

[62] T.-H. Kang, Y. Murakami, H. Takayama et al., "Protective effect of rhynchophylline and isorhynchophylline on in vitro ischemia-induced neuronal damage in the hippocampus: putative neurotransmitter receptors involved in their action," Life Sciences, vol. 76, no. 3, pp. 331-343, 2004.

[63] Z. X. Mo, D. D. Xu, and K. L. Ken, "Effects of rhynchophylline on rat cortical neurons stressed by methamphetamine," Pharmacologyonline, vol. 3, pp. 856-861, 2006.

[64] J.-H. Lu, J.-Q. Tan, S. S. K. Durairajan et al., "Isorhynchophylline, a natural alkaloid, promotes the degradation of $\alpha$-synuclein in neuronal cells via inducing autophagy," Autophagy, vol. 8, no. 1, pp. 98-108, 2012.

[65] S. M. Rothman and J. W. Olney, "Glutamate and the pathophysiology of hypoxic-ischemic brain damage," Annals of Neurology, vol. 19, no. 2, pp. 105-111, 1986.

[66] M. Baba, S. Nakajo, P.-H. Tu et al., "Aggregation of $\alpha$-synuclein in Lewy bodies of sporadic Parkinson's disease and dementia with Lewy bodies," American Journal of Pathology, vol. 152, no. 4, pp. 879-884, 1998.

[67] X. R. Shi, Z. Y. Hong, H. R. Liu, Y. C. Zhang, and Y. Z. Zhu, "Neuroprotective effects of SCM198 on 6-hydroxydopamineinduced behavioral deficit in rats and cytotoxicity in neuronal SH-SY5Y cells," Neurochemistry International, vol. 58, no. 8, pp. 851-860, 2011.

[68] J. Qi, Z. Y. Hong, H. Xin, and Y. Z. Zhu, "Neuroprotective effects of leonurine on ischemia/reperfusion-induced mitochondrial dysfunctions in rat cerebral cortex," Biological \& Pharmaceutical Bulletin, vol. 33, no. 12, pp. 1958-1964, 2010.

[69] K. P. Loh, J. Qi, B. K. H. Tan, X. H. Liu, B. G. Wei, and Y. Z. Zhu, "Leonurine protects middle cerebral artery occluded rats through antioxidant effect and regulation of mitochondrial function," Stroke, vol. 41, no. 11, pp. 2661-2668, 2010.

[70] R. J. Nijveldt, E. Van Nood, D. E. C. Van Hoorn, P. G. Boelens, K. Van Norren, and P. A. M. Van Leeuwen, "Flavonoids: a review of probable mechanisms of action and potential applications," American Journal of Clinical Nutrition, vol. 74, no. 4, pp. 418425, 2001.

[71] J. Robak and R. J. Gryglewski, "Bioactivity of flavonoids," Polish Journal of Pharmacology, vol. 48, no. 6, pp. 555-564, 1996.

[72] G. Bureau, F. Longpré, and M.-G. Martinoli, "Resveratrol and quercetin, two natural polyphenols, reduce apoptotic neuronal cell death induced by neuroinflammation," Journal of Neuroscience Research, vol. 86, no. 2, pp. 403-410, 2008.

[73] Z. J. Zhang, L. C. V. Cheang, M. W. Wang, and S. M.-Y. Lee, "Quercetin exerts a neuroprotective effect through inhibition of the iNOS/NO system and pro-inflammation gene expression in PC12 cells and in zebrafish," International Journal of Molecular Medicine, vol. 27, no. 2, pp. 195-203, 2011.

[74] W.-C. Hou, R.-D. Lin, C.-T. Chen, and M.-H. Lee, "Monoamine oxidase B (MAO-B) inhibition by active principles from Uncaria rhynchophylla,' Journal of Ethnopharmacology, vol. 100, no. 1-2, pp. 216-220, 2005.

[75] L. D. Mercer, B. L. Kelly, M. K. Horne, and P. M. Beart, "Dietary polyphenols protect dopamine neurons from oxidative insults 
and apoptosis: investigations in primary rat mesencephalic cultures," Biochemical Pharmacology, vol. 69, no. 2, pp. 339-345, 2005.

[76] M. Jazvinšćak Jembrek, L. Vuković, J. Puhović, J. Erhardt, and N. Oršolić, "Neuroprotective effect of quercetin against hydrogen peroxide-induced oxidative injury in P19 neurons," Journal of Molecular Neuroscience, vol. 47, no. 2, pp. 286-299, 2012.

[77] N. Haleagrahara, C. J. Siew, N. K. Mitra, and M. Kumari, "Neuroprotective effect of bioflavonoid quercetin in 6-hydroxydopamine-induced oxidative stress biomarkers in the rat striatum," Neuroscience Letters, vol. 500, no. 2, pp. 139-143, 2011.

[78] Y. Shimada, H. Goto, T. Kogure et al., "Protective effect of phenolic compounds isolated from the hooks and stems of Uncaria sinensis on glutamate-induced neuronal death," American Journal of Chinese Medicine, vol. 29, no. 1, pp. 173-180, 2001.

[79] M. A. Ansari, H. M. Abdul, G. Joshi, W. O. Opii, and D. A. Butterfield, "Protective effect of quercetin in primary neurons against $\mathrm{A} \beta(1-42)$ : relevance to Alzheimer's disease," Journal of Nutritional Biochemistry, vol. 20, no. 4, pp. 269-275, 2009.

[80] J. Bournival, P. Quessy, and M.-G. Martinoli, "Protective effects of resveratrol and quercetin against $\mathrm{MPP}+$-induced oxidative stress act by modulating markers of apoptotic death in dopaminergic neurons," Cellular and Molecular Neurobiology, vol. 29, no. 8, pp. 1169-1180, 2009.

[81] N. Suematsu, M. Hosoda, and K. Fujimori, "Protective effects of quercetin against hydrogen peroxide-induced apoptosis in human neuronal SH-SY5Y cells," Neuroscience Letters, vol. 504, no. 3, pp. 223-227, 2011.

[82] F. Pu, K. Mishima, K. Irie et al., "Neuroprotective effects of quercetin and rutin on spatial memory impairment in an 8arm radial maze task and neuronal death induced by repeated cerebral ischemia in rats," Journal of Pharmacological Sciences, vol. 104, no. 4, pp. 329-334, 2007.

[83] F. Rivera, G. Costa, A. Abin et al., "Reduction of ischemic brain damage and increase of glutathione by a liposomal preparation of quercetin in permanent focal ischemia in rats," Neurotoxicity Research, vol. 13, no. 2, pp. 105-114, 2008.

[84] C. A. Rice-Evans, N. J. Miller, P. G. Bolwell, P. M. Bramley, and J. B. Pridham, "The relative antioxidant activities of plant-derived polyphenolic flavonoids," Free Radical Research, vol. 22, no. 4, pp. 375-383, 1995.

[85] K. A. Youdim and J. A. Joseph, "A possible emerging role of phytochemicals in improving age-related neurological dysfunctions: a multiplicity of effects," Free Radical Biology and Medicine, vol. 30, no. 6, pp. 583-594, 2001.

[86] B. Ossola, T. M. Kääriäinen, and P. T. Männistö, "The multiple faces of quercetin in neuroprotection," Expert Opinion on Drug Safety, vol. 8, no. 4, pp. 397-409, 2009.

[87] F. Dajas, G. Costa, J. A. Abín-Carriquiry, R. McGregor, and J. Urbanavicius, "Involvement of nicotinic acetylcholine receptors in the protection of dopamine terminals in experimental Parkinsonism," Functional Neurology, vol. 16, no. 4, pp. 113-123, 2001.

[88] A. R. Tapas, D. M. Sakarkar, and R. B. Kakde, "Flavonoids as nutraceuticals: a review," Tropical Journal of Pharmaceutical Research, vol. 7, pp. 1089-1099, 2008.

[89] Y.-C. Chen, S.-C. Shen, W.-R. Lee, W.-C. Hou, L.-L. Yang, and T. J. F. Lee, "Inhibition of nitric oxide synthase inhibitors and lipopolysaccharide induced inducible NOS and cyclooxygenase-2 gene expressions by rutin, quercetin, and quercetin pentaacetate in RAW 264.7 macrophages,"
Journal of Cellular Biochemistry, vol. 82, no. 4, pp. 537-548, 2001.

[90] S.-W. Wang, Y.-J. Wang, Y.-J. Su et al., "Rutin inhibits $\beta$-amyloid aggregation and cytotoxicity, attenuates oxidative stress, and decreases the production of nitric oxide and proinflammatory cytokines," NeuroToxicology, vol. 33, no. 3, pp. 482-490, 2012.

[91] M. Moshahid Khan, S. S. Raza, H. Javed et al., "Rutin protects dopaminergic neurons from oxidative stress in an animal model of Parkinson's disease," Neurotoxicity Research, vol. 22, no. 1, pp. $1-15,2011$.

[92] T. Koda, Y. Kuroda, and H. Imai, "Rutin supplementation in the diet has protective effects against toxicant-induced hippocampal injury by suppression of microglial activation and proinflammatory cytokines : protective effect of rutin against toxicant-induced hippocampal injury," Cellular and Molecular Neurobiology, vol. 29, no. 4, pp. 523-531, 2009.

[93] F. Pu, K. Mishima, K. Irie et al., "Neuroprotective effects of quercetin and rutin on spatial memory impairment in an 8arm radial maze task and neuronal death induced by repeated cerebral ischemia in rats," Journal of Pharmacological Sciences, vol. 104, no. 4, pp. 329-334, 2007.

[94] F.-Q. Li, T. Wang, Z. Pei, B. Liu, and J.-S. Hong, "Inhibition of microglial activation by the herbal flavonoid baicalein attenuates inflammation-mediated degeneration of dopaminergic neurons," Journal of Neural Transmission, vol. 112, no. 3, pp. 331347, 2005.

[95] G. Xu, J. Dou, L. Zhang, Q. Guo, and C. Zhou, "Inhibitory effects of baicalein on the influenza virus in vivo is determined by baicalin in the serum," Biological \& Pharmaceutical Bulletin, vol. 33, no. 2, pp. 238-243, 2010.

[96] E. K. C. Kong, S. Yu, J. E. Sanderson, K.-B. Chen, Y. Huang, and C.-M. Yu, "A novel anti-fibrotic agent, baicalein, for the treatment of myocardial fibrosis in spontaneously hypertensive rats," European Journal of Pharmacology, vol. 658, no. 2-3, pp. 175-181, 2011.

[97] K. Y. Hwang, Y. T. Oh, H. Yoon et al., "Baicalein suppresses hypoxia-induced HIF- $1 \alpha$ protein accumulation and activation through inhibition of reactive oxygen species and PI 3kinase/Akt pathway in BV2 murine microglial cells," Neuroscience Letters, vol. 444, no. 3, pp. 264-269, 2008.

[98] C.-J. Chen, S.-L. Raung, S.-L. Liao, and S.-Y. Chen, "Inhibition of inducible nitric oxide synthase expression by baicalein in endotoxin/cytokine-stimulated microglia," Biochemical Pharmacology, vol. 67, no. 5, pp. 957-965, 2004.

[99] H. J. Lee, Y. H. Noh, D. Y. Lee et al., "Baicalein attenuates 6hydroxydopamine-induced neurotoxicity in SH-SY5Y cells," European Journal of Cell Biology, vol. 84, no. 11, pp. 897-905, 2005.

[100] X. Mu, G. He, Y. Cheng, X. Li, B. Xu, and G. Du, "Baicalein exerts neuroprotective effects in 6-hydroxydopamine-induced experimental parkinsonism in vivo and in vitro," Pharmacology Biochemistry and Behavior, vol. 92, no. 4, pp. 642-648, 2009.

[101] J. H. Choi, A. Y. Choi, H. Yoon et al., "Baicalein protects HT22 murine hippocampal neuronal cells against endoplasmic reticulum stress-induced apoptosis through inhibition of reactive oxygen species production and CHOP induction," Experimental and Molecular Medicine, vol. 42, no. 12, pp. 811-822, 2010.

[102] Y.-C. Chen, J.-M. Chow, C.-W. Lin, C.-Y. Wu, and S.-C. Shen, "Baicalein inhibition of oxidative-stress-induced apoptosis via modulation of ERKs activation and induction of HO-1 gene expression in rat glioma cells C6," Toxicology and Applied Pharmacology, vol. 216, no. 2, pp. 263-273, 2006. 
[103] X.-X. Li, G.-R. He, X. Mu et al., "Protective effects of baicalein against rotenone-induced neurotoxicity in PC12 cells and isolated rat brain mitochondria," European Journal of Pharmacology, vol. 674, no. 2-3, pp. 227-233, 2012.

[104] S.-F. Chen, C.-W. Hsu, W.-H. Huang, and J.-Y. Wang, "Postinjury baicalein improves histological and functional outcomes and reduces inflammatory cytokines after experimental traumatic brain injury," British Journal of Pharmacology, vol. 155, no. 8, pp. 1279-1296, 2008.

[105] K.-W. Kim, K.-T. Ha, C.-S. Park et al., "Polygonum cuspidatum, compared with baicalin and berberine, inhibits inducible nitric oxide synthase and cyclooxygenase-2 gene expressions in RAW 264.7 macrophages," Vascular Pharmacology, vol. 47, no. 2-3, pp. 99-107, 2007.

[106] L.-L. Liu, L.-K. Gong, H. Wang et al., "Baicalin inhibits macrophage activation by lipopolysaccharide and protects mice from endotoxin shock," Biochemical Pharmacology, vol. 75, no. 4, pp. 914-922, 2008.

[107] C.-T. Li, W.-P. Zhang, S.-H. Fang et al., "Baicalin attenuates oxygen-glucose deprivation-induced injury by inhibiting oxidative stress-mediated 5-lipoxygenase activation in PC12 cells," Acta Pharmacologica Sinica, vol. 31, no. 2, pp. 137-144, 2010.

[108] X.-K. Tu, W.-Z. Yang, S.-S. Shi, C.-H. Wang, and C.-M. Chen, "Neuroprotective effect of baicalin in a rat model of permanent focal cerebral ischemia," Neurochemical Research, vol. 34, no. 9, pp. 1626-1634, 2009.

[109] X.-K. Tu, W.-Z. Yang, S.-S. Shi et al., "Baicalin inhibits TLR2/4 signaling pathway in rat brain following permanent cerebral ischemia," Inflammation, vol. 34, no. 5, pp. 463-470, 2011.

[110] X. Xue, X.-J. Qu, Y. Yang et al., "Baicalin attenuates focal cerebral ischemic reperfusion injury through inhibition of nuclear factor $\kappa \mathrm{B}$ p65 activation," Biochemical and Biophysical Research Communications, vol. 403, no. 3-4, pp. 398-404, 2010.

[111] Y. Cao, G. Li, Y.-F. Wang et al., "Neuroprotective effect of baicalin on compression spinal cord injury in rats," Brain Research, vol. 1357, pp. 115-123, 2010.

[112] I. Wakabayashi and K. Yasui, "Wogonin inhibits inducible prostaglandin E2 production in macrophages," European Journal of Pharmacology, vol. 406, no. 3, pp. 477-481, 2000.

[113] S.-C. Shen, W.-R. Lee, H.-Y. Lin et al., "In vitro and in vivo inhibitory activities of rutin, wogonin, and quercetin on lipopolysaccharide-induced nitric oxide and prostaglandin $\mathrm{E}_{2}$ production," European Journal of Pharmacology, vol. 446, no. 1-3, pp. 187-194, 2002.

[114] I. Wakabayashi, "Inhibitory effects of baicalein and wogonin on lipopolysaccharide-induced nitric oxide production in macrophages," Pharmacology and Toxicology, vol. 84, no. 6, pp. 288-291, 1999.

[115] G.-C. Huang, J.-M. Chow, S.-C. Shen, L.-Y. Yang, C.-W. Lin, and Y.-C. Chen, "Wogonin but not Nor-wogonin inhibits lipopolysaccharide and lipoteichoic acid-induced iNOS gene expression and NO production in macrophages," International Immunopharmacology, vol. 7, no. 8, pp. 1054-1063, 2007.

[116] H. Z. Piao, S. A. Jin, H. S. Chun, J. C. Lee, and W. K. Kim, "Neuroprotective effect of wogonin: potential roles of inflammatory cytokines," Archives of Pharmacal Research, vol. 27, no. 9, pp. 930-936, 2004.

[117] H. Z. Piao, I. Y. Choi, J.-S. Park et al., "Wogonin inhibits microglial cell migration via suppression of nuclear factor-kappa B activity," International Immunopharmacology, vol. 8, no. 12, pp. 1658-1662, 2008.
[118] Y.-C. Chen, S.-C. Shen, L.-G. Chen, T. J.-F. Lee, and L.-L. Yang, "Wogonin, baicalin, and baicalein inhibition of inducible nitric oxide synthase and cyclooxygenase-2 gene expressions induced by nitric oxide synthase inhibitors and lipopolysaccharide," Biochemical Pharmacology, vol. 61, no. 11, pp. 1417-1427, 2001.

[119] J. Cho and H.-K. Lee, "Wogonin inhibits ischemic brain injury in a rat model of permanent middle cerebral artery occlusion," Biological \& Pharmaceutical Bulletin, vol. 27, no. 10, pp. 15611564, 2004.

[120] Y.-C. Chen, L.-L. Yang, and T. J.-F. Lee, "Oroxylin A inhibition of lipopolysaccharide-induced iNOS and COX-2 gene expression via suppression of nuclear factor- $\kappa \mathrm{B}$ activation," Biochemical Pharmacology, vol. 59, no. 11, pp. 1445-1457, 2000.

[121] K. M. You, H.-G. Jong, and H. P. Kim, "Inhibition of cyclooxygenase/lipoxygenase from human platelets by polyhydroxylated/methoxylated flavonoids isolated from medicinal plants," Archives of Pharmacal Research, vol. 22, no. 1, pp. 18-24, 1999.

[122] D. H. Kim, S. Kim, S. J. Jeon et al., "The effects of acute and repeated oroxylin A treatments on A $\beta 25$-35-induced memory impairment in mice," Neuropharmacology, vol. 55, no. 5, pp. 639-647, 2008.

[123] Y.-C. Liang, Y.-T. Huang, S.-H. Tsai, S.-Y. Lin-Shiau, C.-F. Chen, and J.-K. Lin, "Suppression of inducible cyclooxygenase and inducible nitric oxide synthase by apigenin and related flavonoids in mouse macrophages," Carcinogenesis, vol. 20, no. 10, pp. 1945-1952, 1999.

[124] S. Hougee, A. Sanders, J. Faber et al., "Decreased pro-inflammatory cytokine production by LPS-stimulated PBMC upon in vitro incubation with the flavonoids apigenin, luteolin or chrysin, due to selective elimination of monocytes/macrophages," Biochemical Pharmacology, vol. 69, no. 2, pp. 241-248, 2005.

[125] J. Kowalski, A. Samojedny, M. Paul, G. Pietsz, and T. Wilczok, "Effect of apigenin, kaempferol and resveratrol on the expression of interleukin- $1 \beta$ and tumor necrosis factor- $\alpha$ genes in J774.2 macrophages," Pharmacological Reports, vol. 57, no. 3, pp. 390-394, 2005.

[126] S. K. Ha, P. Lee, J. A. Park et al., "Apigenin inhibits the production of NO and PGE2 in microglia and inhibits neuronal cell death in a middle cerebral artery occlusion-induced focal ischemia mice model," Neurochemistry International, vol. 52, no. 4-5, pp. 878-886, 2008.

[127] M. Hämäläinen, R. Nieminen, M. Z. Asmawi, P. Vuorela, H. Vapaatalo, and E. Moilanen, "Effects of flavonoids on prostaglandin E2 production and on COX-2 and mPGES-1 expressions in activated macrophages," Planta Medica, vol. 77, no. 13, pp. 1504-1511, 2011.

[128] M. Hämäläinen, R. Nieminen, P. Vuorela, M. Heinonen, and E. Moilanen, "Anti-inflammatory effects of flavonoids: genistein, kaempferol, quercetin, and daidzein inhibit STAT-1 and NF$\kappa \mathrm{B}$ activations, whereas flavone, isorhamnetin, naringenin, and pelargonidin inhibit only NF- $\kappa \mathrm{B}$ activation along with their inhibitory effect on iNOS expression and NO production in activated macrophages," Mediators of Inflammation, vol. 2007, Article ID 45673, 10 pages, 2007.

[129] O. A. Harasstani, S. Moin, C. L. Tham et al., "Flavonoid combinations cause synergistic inhibition of proinflammatory mediator secretion from lipopolysaccharide-induced RAW 264.7 cells," Inflammation Research, vol. 59, no. 9, pp. 711-721, 2010.

[130] C. López-Sánchez, F. J. Martín-Romero, F. Sun et al., "Blood micromolar concentrations of kaempferol afford protection against ischemia/reperfusion-induced damage in rat brain," Brain Research, vol. 1182, no. 1, pp. 123-137, 2007. 
[131] S.-J. Kim, J.-Y. Um, S.-H. Hong, and J.-Y. Lee, “Anti-inflammatory activity of hyperoside through the suppression of nuclear factor- $\kappa \mathrm{B}$ activation in mouse peritoneal macrophages," American Journal of Chinese Medicine, vol. 39, no. 1, pp. 171-181, 2011.

[132] Z. Liu, X. Tao, C. Zhang, Y. Lu, and D. Wei, "Protective effects of hyperoside (quercetin-3-o-galactoside) to PC12 cells against cytotoxicity induced by hydrogen peroxide and tert-butyl hydroperoxide," Biomedicine and Pharmacotherapy, vol. 59, no. 9, pp. 481-490, 2005.

[133] L. Zhang, X.-R. Cheng, J.-J. Hu, L. Sun, and G.-H. Du, "Neuroprotective effects of hyperoside on sodium azide-induced apoptosis in PC12 cells," Chinese Journal of Natural Medicines, vol. 9, no. 6, pp. 450-455, 2011.

[134] H.-Y. Chen, J.-H. Wang, Z.-X. Ren, and X.-B. Yang, "Protective effect of hyperin on focal cerebral ischemia reperfusion injury in rats," Journal of Chinese Integrative Medicine, vol. 4, no. 5, pp. 526-529, 2006.

[135] R. Tundis, M. R. Loizzo, F. Menichini, G. A. Statti, and F. Menichini, "Biological and pharmacological activities of iridoids: recent developments," Mini-Reviews in Medicinal Chemistry, vol. 8, no. 4, pp. 399-420, 2008.

[136] Q.-S. Wang, Y. Xiang, Y.-L. Cui, K.-M. Lin, and X.-F. Zhang, "Dietary blue pigments derived from genipin, attenuate inflammation by inhibiting LPS-induced iNOS and COX-2 expression via the NF- $\kappa$ B inactivation," PLoS ONE, vol. 7, no. 3, Article ID e34122, 2012.

[137] K. N. Nam, Y.-S. Choi, H.-J. Jung et al., "Genipin inhibits the inflammatory response of rat brain microglial cells," International Immunopharmacology, vol. 10, no. 4, pp. 493-499, 2010.

[138] H.-J. Koo, K.-H. Lim, H.-J. Jung, and E.-H. Park, "Antiinflammatory evaluation of gardenia extract, geniposide and genipin," Journal of Ethnopharmacology, vol. 103, no. 3, pp. 496500, 2006.

[139] F. Yin, J.-H. Liu, X.-X. Zheng, and L.-X. Guo, "GLP-1 receptor plays a critical role in geniposide-induced expression of heme oxygenase-1 in PC12 cells," Acta Pharmacologica Sinica, vol. 31, no. 5, pp. 540-545, 2010.

[140] J. Liu, F. Yin, X. Zheng, J. Jing, and Y. Hu, "Geniposide, a novel agonist for GLP-1 receptor, prevents PC12 cells from oxidative damage via MAP kinase pathway," Neurochemistry International, vol. 51, no. 6-7, pp. 361-369, 2007.

[141] J.-H. Liu, F. Yin, L.-X. Guo, X.-H. Deng, and Y.-H. Hu, "Neuroprotection of geniposide against hydrogen peroxide induced PC12 cells injury: involvement of PI3 kinase signal pathway," Acta Pharmacologica Sinica, vol. 30, no. 2, pp. 159-165, 2009.

[142] F. Yin, J. Liu, X. Zheng, L. Guo, and H. Xiao, "Geniposide induces the expression of heme oxygenase-1 via PI3K/Nrf2signaling to enhance the antioxidant capacity in primary hippocampal neurons," Biological \& Pharmaceutical Bulletin, vol. 33, no. 11, pp. 1841-1846, 2010.

[143] M. Yamazaki, K. Chiba, and C. Yoshikawa, "Genipin suppresses A23187-induced cytotoxicity in Neuro2a cells," Biological \& Pharmaceutical Bulletin, vol. 32, no. 6, pp. 1043-1046, 2009.

[144] M. Yamazaki, K. Chiba, and K. Satoh, "Neuro2a cell death induced by 6-hydroxydopamine is attenuated by genipin," Journal of Health Science, vol. 54, no. 6, pp. 638-644, 2008.

[145] M. Yamazaki, N. Sakura, K. Chiba, and T. Mohri, "Prevention of the neurotoxicity of the amyloid $\beta$ protein by genipin," Biological \& Pharmaceutical Bulletin, vol. 24, no. 12, pp. 14541455, 2001.

[146] M. Tanaka, M. Yamazaki, and K. Chiba, "Neuroprotective action of genipin on tunicamycin-induced cytotoxicity in neuro2a cells," Biological \& Pharmaceutical Bulletin, vol. 32, no. 7, pp. 1220-1223, 2009.

[147] L.-X. Guo, J.-H. Liu, and Z.-N. Xia, "Geniposide inhibits CoCl2induced PC12 cells death via the mitochondrial pathway," Chinese Medical Journal, vol. 122, no. 23, pp. 2886-2892, 2009.

[148] P. Lee, J. Lee, S. Y. Choi, S. E. Lee, S. Lee, and D. Son, “Geniposide from Gardenia jasminoides attenuates neuronal cell death in oxygen and glucose deprivation-exposed rat hippocampal slice culture," Biological \& Pharmaceutical Bulletin, vol. 29, no. 1, pp. 174-176, 2006.

[149] M. Yamazaki, K. Chiba, T. Mohri, and H. Hatanaka, "Activation of the mitogen-activated protein kinase cascade through nitric oxide synthesis as a mechanism of neuritogenic effect of genipin in PC12h cells," Journal of Neurochemistry, vol. 79, no. 1, pp. 45$54,2001$.

[150] M. Yamazaki, K. Chiba, T. Mohri, and H. Hatanaka, "Cyclic GMP-dependent neurite outgrowth by genipin and nerve growth factor in PC12h cells," European Journal of Pharmacology, vol. 488, no. 1-3, pp. 35-43, 2004.

[151] M. Yamazaki and K. Chiba, "Genipin exhibits neurotrophic effects through a common signaling pathway in nitric oxide synthase-expressing cells," European Journal of Pharmacology, vol. 581, no. 3, pp. 255-261, 2008.

[152] M. Yamazaki, K. Chiba, and T. Mohri, "Neuritogenic effect of natural iridoid compounds on $\mathrm{PC1} 2 \mathrm{~h}$ cells and its possible relation to signaling protein kinases," Biological \& Pharmaceutical Bulletin, vol. 19, no. 6, pp. 791-795, 1996.

[153] P. H. Evans, "Free radicals in brain metabolism and pathology," British Medical Bulletin, vol. 49, no. 3, pp. 577-587, 1993.

[154] R. Edge, D. J. McGarvey, and T. G. Truscott, "The carotenoids as anti-oxidants-a review," Journal of Photochemistry and Photobiology B, vol. 41, no. 3, pp. 189-200, 1997.

[155] D. A. Cooper, A. L. Eldridge, and J. C. Peters, "Dietary carotenoids and certain cancers, heart disease, and age-related macular degeneration: a review of recent research," Nutrition Reviews, vol. 57, no. 7, pp. 201-214, 1999.

[156] M. Etminan, S. S. Gill, and A. Samii, "Intake of vitamin E, vitamin $\mathrm{C}$, and carotenoids and the risk of Parkinson's disease: meta-analysis," Lancet Neurology, vol. 4, no. 6, pp. 362-365, 2005.

[157] F. Yoshino, A. Yoshida, N. Umigai, K. Kubo, and M.-C. Lee, "Crocetin reduces the oxidative stress induced reactive oxygen species in the stroke-prone spontaneously hypertensive rats (SHRSPs) brain," Journal of Clinical Biochemistry and Nutrition, vol. 49, no. 3, pp. 182-187, 2011.

[158] M. A. Papandreou, M. Tsachaki, S. Efthimiopoulos, P. Cordopatis, F. N. Lamari, and M. Margarity, "Memory enhancing effects of saffron in aged mice are correlated with antioxidant protection," Behavioural Brain Research, vol. 219, no. 2, pp. 197204, 2011.

[159] A. S. Ahmad, M. A. Ansari, M. Ahmad et al., "Neuroprotection by crocetin in a hemi-parkinsonian rat model," Pharmacology Biochemistry and Behavior, vol. 81, no. 4, pp. 805-813, 2005.

[160] X. Xu, Y. Lu, and X. Bie, "Protective effects of gastrodin on hypoxia-induced toxicity in primary cultures of rat cortical neurons," Planta Medica, vol. 73, no. 7, pp. 650-654, 2007.

[161] X. Zeng, S. Zhang, L. Zhang, K. Zhang, and X. Zheng, "A study of the neuroprotective effect of the phenolic glucoside gastrodin during cerebral ischemia in vivo and in vitro," Planta Medica, vol. 72, no. 15, pp. 1359-1365, 2006. 
[162] J.-N. Dai, Y. Zong, L.-M. Zhong et al., “Gastrodin inhibits expression of inducible no synthase, cyclooxygenase-2 and proinflammatory cytokines in cultured LPS-Stimulated microglia via MAPK pathways," PLoS ONE, vol. 6, no. 7, Article ID e21891, 2011.

[163] X. Bie, Y. Chen, J. Han, H. Dai, H. Wan, and T. Zhao, "Effects of gastrodin on amino acids after cerebral ischemia-reperfusion injury in rat striatum," Asia Pacific Journal of Clinical Nutrition, vol. 16, no. 1, pp. 305-308, 2007.

[164] S. Kim, H. Park, Y. Song et al., "Reduction of oxidative stress by p-hydroxybenzyl alcohol-containing biodegradable polyoxalate nanoparticulate antioxidant," Biomaterials, vol. 32, no. 11, pp. 3021-3029, 2011.

[165] B.-W. Kim, S. Koppula, J.-W. Kim et al., "Modulation of LPSstimulated neuroinflammation in BV-2 microglia by Gastrodia elata: 4-hydroxybenzyl alcohol is the bioactive candidate," Journal of Ethnopharmacology, vol. 139, no. 2, pp. 549-557, 2012.

[166] K.-Y. Kam, S. J. Yu, N. Jeong et al., "p-hydroxybenzyl alcohol prevents brain injury and behavioral impairment by activating Nrf2, PDI, and neurotrophic factor genes in a rat model of brain ischemia," Molecules and Cells, vol. 31, no. 3, pp. 209-215, 2011.

[167] S. J. Yu, J. R. Kim, C. K. Lee et al., "Gastrodia elata blume and an active component, p-hydroxybenzyl alcohol reduce focal ischemic brain injury through antioxidant related gene expressions," Biological \& Pharmaceutical Bulletin, vol. 28, no. 6, pp. 10161020, 2005. 

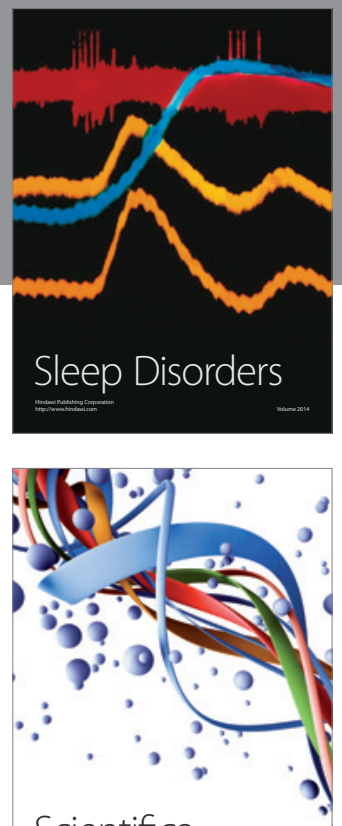

Scientifica
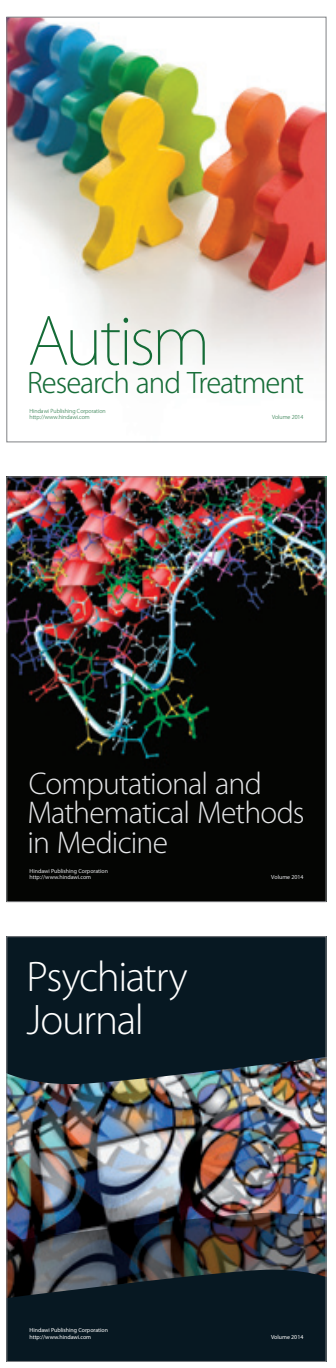
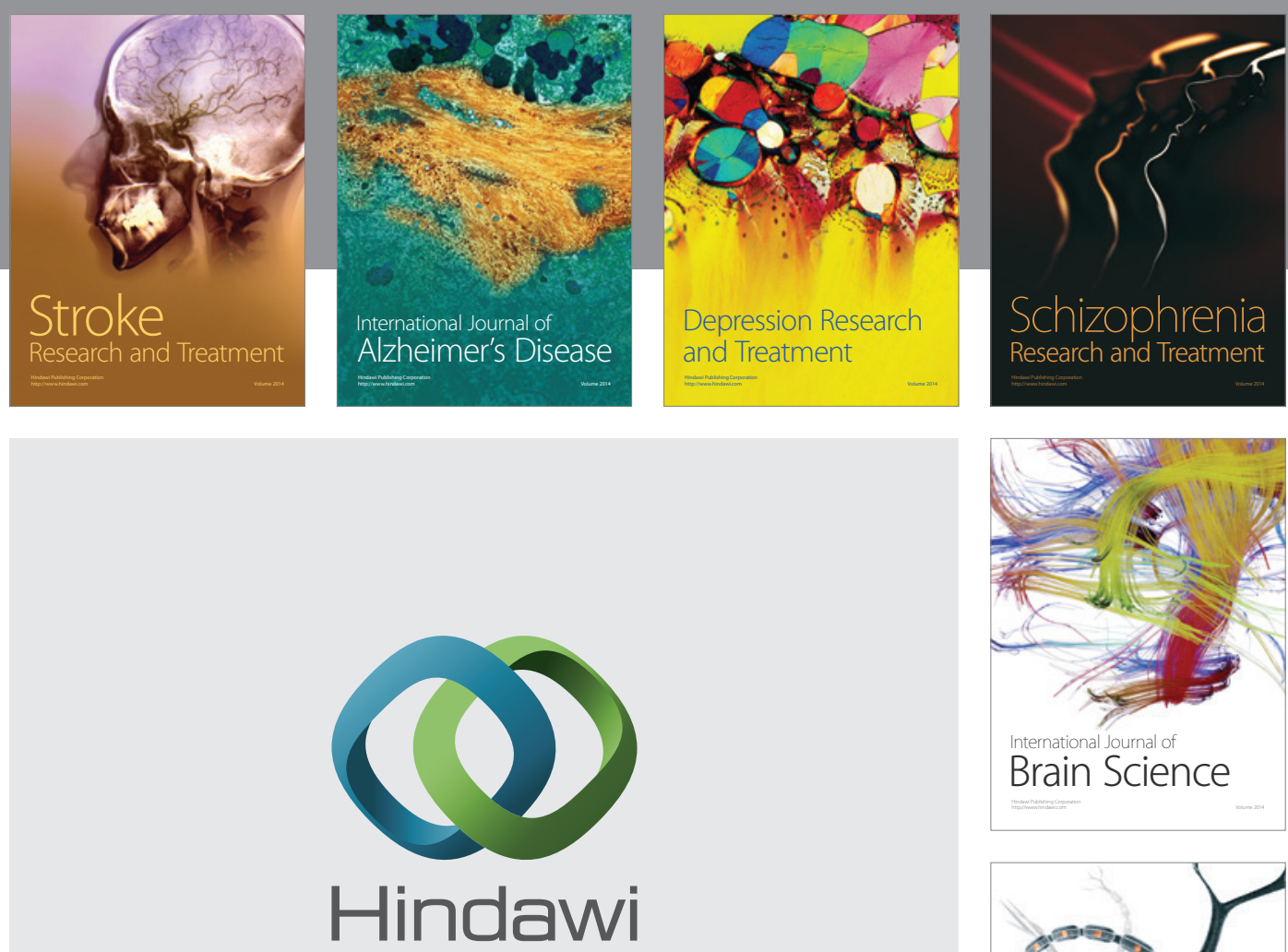

Submit your manuscripts at

http://www.hindawi.com
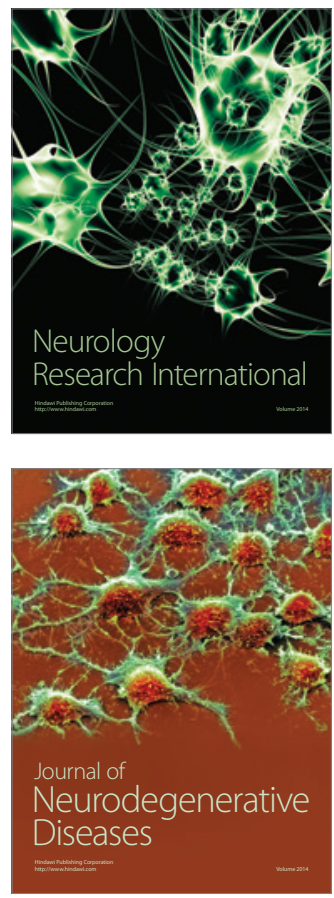

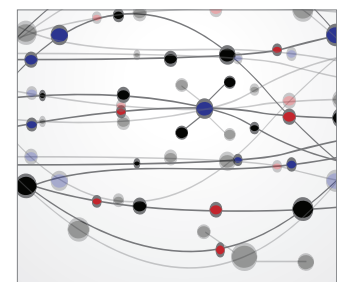

The Scientific World Journal
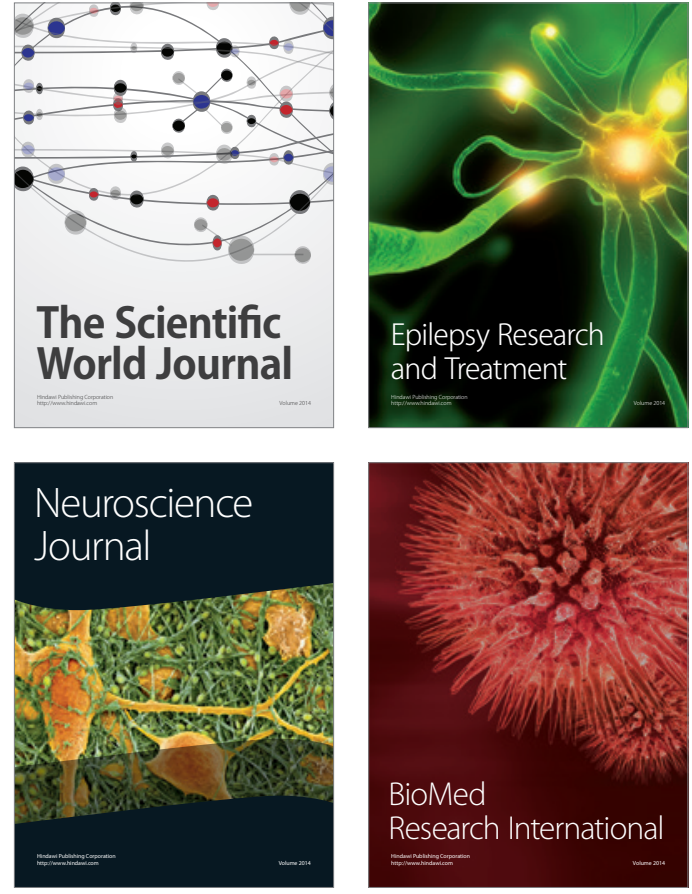

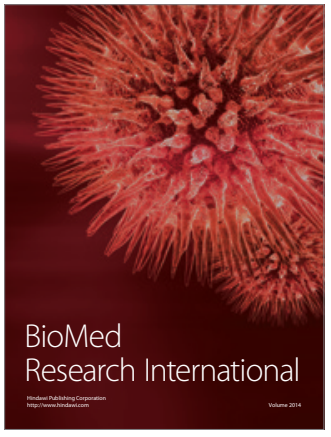

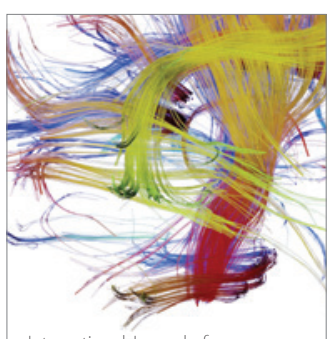

Brain Science

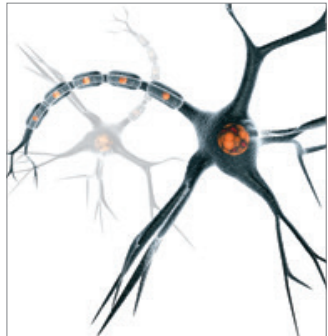

Neural Plasticity
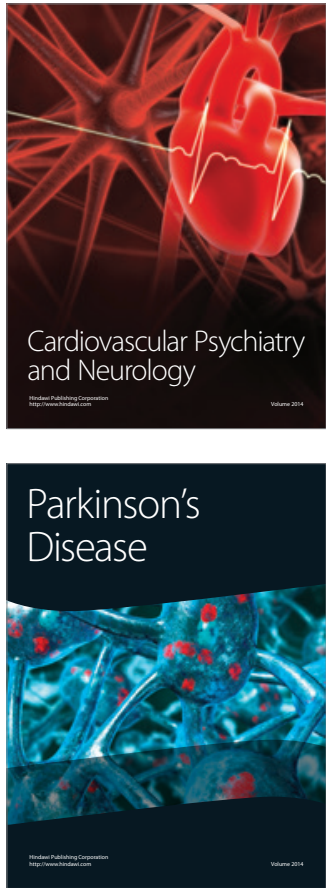